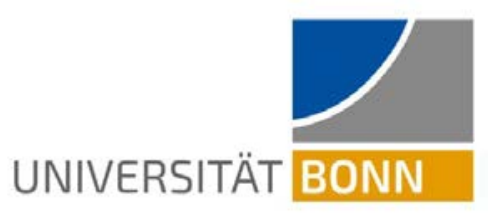

Discussion Paper No. 259

Project B 05

\title{
Market Definition in the Platform Economy
}

\author{
Jens-Uwe Franck ${ }^{1}$ \\ Martin Peitz ${ }^{2}$
}

March 2021

(First version : January 2021)

\footnotetext{
${ }^{1}$ Department of Law and MaCCl, University of Mannheim

${ }^{2}$ Department of Economics and MaCCl, University of Mannheim.
}

Funding by the Deutsche Forschungsgemeinschaft (DFG, German Research Foundation) through CRC TR 224 is gratefully acknowledged. 


\title{
Market Definition in the Platform Economy ${ }^{*}$
}

\author{
Jens-Uwe Franck ${ }^{\dagger}$ and Martin Peitz ${ }^{\ddagger}$
}

01 March 2021

\section{ABSTRACT}

The article addresses the role market definition can play for EU competition practice in the platform economy. The focus is on intermediaries that bring together two (or more) groups of users whose decisions are interdependent and which therefore are commonly referred to as "two-sided platforms". We address challenges to market definition that accompany these cross-group network effects, assess current practice in a number of cases with the European Commission and Member States' competition authorities, and provide guidance on how practice is to be adapted to properly account for the economic forces shaping markets with twosided platforms. Owing to the complementarities of services provided to the user groups the platforms cater to, the question arises whether and when a single market can be defined that encompasses both sides. We advocate a multi-markets approach that takes account of cross-market linkages, acknowledges the existence of zero-price markets, and properly accounts for the homing behaviour of market participants.

Keywords: antitrust law; EU competition practice; market definition; market power; Market Definition Notice; two-sided platforms; digital markets; network effects; matching platforms; zero-price markets; homing decisions; SSNIP test

JEL classification: K21

\footnotetext{
* The authors gratefully acknowledge support from the Deutsche Forschungsgemeinschaft through CRC TR 224 (project B05). Parts of this article build on a report the authors prepared for the Centre on Regulation in Europe (CERRE) ("Market Definition and Market Power in the Platform Economy", May 2019).

† Department of Law and $\mathrm{MaCCl}$, University of Mannheim.

$\ddagger$ Department of Economics and $\mathrm{MaCCl}$, University of Mannheim.
} 


\section{CONTENTS}

I. INTRODUCTION 3

II. WHY THE COMMISSION IS RIGHT TO ATTACH IMPORTANCE TO MARKET DEFINITION IN (DIGITAL) PLATFORM MARKETS

1. The positivist angle: EU competition law requires to define markets ___ 6

2. On the jurisprudential function of market definition and why the Commission should be concerned about it

3. Avoiding the need for amendments to competition law and new ex ante regulation

III. MAJOR CHALLENGES POSED BY THE TWO-SIDEDNESS OF PLATFORMS AND HOW TO COPE WITH THEM

1. Single-market approach vs. multi-markets approach

a) Established EU competition practice: multi-markets approach to payment card systems 12

b) On the (in)adequacy of a single-market approach in the case of matching platforms 12

c) Conclusions

2. Markets without a price

a) Why do zero-price markets exist? 17

b) Past EU competition practice: (unfounded) reluctance to define "viewers' markets" 18

c) On the acknowledgement of zero-price markets in the world of digital platforms _ 19

d) Conclusions

3. Market delineation and homing decisions

a) Identifying homing patterns ___ 22

b) The multi-homing/single-homing framework _ 23

4. Multiple markets on one side of a platform 24

a) Multi-purpose platforms 24

b) Regional markets __ 25

c) One-stop vs. multi-stop shopping__ 26

5. The SSNIP test 26

IV. CONSIDERING CONCEPTUAL INTERDEPENDENCIES: MARKET DEFINITION, MARKET POWER AND CROSS-GROUP NETWORK EFFECTS

1. Market shares as a proxy for market power: mitigating and aggravating factors 31

2. Market definition must not (conclusively) determine the scope of the competition analysis _ 33

v. CONCLUSION 34 


\section{Introduction}

Market definition belongs to the small group of concepts that are essential to all instruments of EU competition law: ${ }^{1}$ the prohibition of anti-competitive coordination ${ }^{2}$ and abusive practices, ${ }^{3}$ as well as merger control. ${ }^{4}$ It is primarily ${ }^{5}$ employed as a first step to assess a firm's market power. ${ }^{6}$ The definition of a market is meant to provide a framework that facilitates identifying the competitive constraints market players face. Thus, market definition is used to narrow down an area to which the analysis of factors can be constrained that are relevant for determining market power, as well as to identify barriers to entry. ${ }^{7}$

When, in 1997, the European Commission issued its current Market Definition Notice, the rise of the digital platform economy was still to come. Today, it is the digital platforms that appear to pose the greatest challenges to competition practice: search engines, social networks, online marketplaces, mobile operating systems and app stores, online travel agencies, video platforms, real-estate portals and the like. What characterizes these platforms is that they create and manage network effects, ${ }^{8}$ particularly ${ }^{9}$ as they act as intermediaries between different user groups who are linked through cross-group network effects, ${ }^{10}$ a feature that is commonly referred to as "two-sidedness": ${ }^{11}$ decisions of users in one group are materially dependent on the decisions of users in another group and the platform operator has the opportunity to significantly influence those decisions.

${ }^{1}$ Note that we do not include State aid law in our analysis. While market definition is also relevant to applying State aid law, the concept has not yet been developed and applied in an equally rigorous way as in cartel, abuse and merger cases. See Sousa Ferro, Market Definition in EU Competition Law (Elgar, 2019), pp. 91-96.

2 Art. 101 TFEU.

${ }^{3}$ Art. 102 TFEU.

${ }^{4}$ Council Regulation (EC) No 139/2004 of 20 Jan. 2004 on the control of concentrations between undertakings (the EC Merger Regulation). O.J. 2004, L 24/1.

${ }^{5}$ On the objectives of market definition see Sousa Ferro, op. cit. supra note 1, pp. 29-36; Hahne, Das Erfordernis der Marktabgrenzung aus rechtlicher und ökonomischer Sicht (Nomos, 2016), pp. 27-36.

6 Commission Notice on the definition of relevant market for the purposes of Community competition law. O.J. 1997, C 372/5 (in the following referred to as "Market Definition Notice"), para 2.

7 OECD, "Market definition, policy roundtables, background note by the Secretariat", DAF/COMP(2012)19, pp. 28-29.

8 For an introduction to the economics of network effects, see, e.g., Belleflamme and Peitz, "Platforms and network effects" in Corchon and Marini (Eds), Handbook of Game Theory and Industrial Organization, vol. II (Edward Elgar, 2018), pp. 286-317.

9 "Two-sidedness" is not a necessary precondition for the creation and management of network effects: a social network facilitates interaction between users on one side. An online shop that gives buyers the option to review, recommend or rate products available for sale allows for the creation of direct network effects across its customers. For that reason alone, it is reasonable with regard to many policy questions that arise due to digitization to focus on these scenarios and conceptualize such market players as (digital) "platforms". See, for instance, Regulation (EU) 2019/1150 of the European Parliament and of the Council of 20 June 2019 on promoting fairness and transparency for business users of online intermediation services, O.J. 2019 L 186/57. However, the main challenges with regard to the competition law concept of market definition are indeed based on the characteristic of "two-sidedness".

${ }_{10}$ We speak of a positive cross-group network effect that side A exerts on side B if a user on side B benefits if more users on side $A$ participate (or if users on side $A$ increase their usage volume). If these cross-group network effects operate in both directions, then there are indirect network effects on each side. For example, a user on side $A$ indirectly benefits from more users on its own side because these users make it more attractive for users on side $B$ to join; additional users on side $B$ then benefit the user on side $A$.

11 Certainly, many platforms cater to more than two groups that are linked through cross-group network effects and should therefore be called "multi-sided". Since the term "two-sided platform" is widely used, we follow this convention with the understanding that at least two groups are involved. 
How these interdependencies between two or more user groups should be taken into account when defining markets raises a number of fundamental issues that were not addressed in the Market Definition Notice of $1997 .{ }^{12}$ This is remarkable because two-sidedness is not a feature unique to digital platforms. Capturing the business models of newspapers, (adfinanced) TV, payment card systems or shopping centres - to name but a few instances of "traditional" two-sided platforms - poses essentially the same problems. However, digital platforms have gained more prominence because their business model is often scalable and thus, they raise more public interest both in general and, more particularly, in competition policy concerns. It is against this background that, in the last two decades, the economic theory of two-sided markets has experienced considerable progress and its implications for competition policy have been widely discussed.

Adapting the Market Definition Notice to meet the realities and challenges posed by the rise of digital platforms will therefore be the central concern of the review of the Notice launched by the Commission in April 2020. ${ }^{13}$ Thus, this evaluation must be seen as one of a series of measures by the Commission to adapt the EU competition law framework so that it can cope with the (digital) platform economy. In this vein, the Commission is also about to reform the Vertical Block Exemption Regulation, ${ }^{14}$ is considering several calibrations to the EU merger rules, ${ }^{15}$ and has proposed a "Digital Markets Act". ${ }^{16}$

The remainder of this article is structured as follows. In Section II we explain that the Commission, national competition authorities and courts are indeed well advised to pay attention to market definition precisely because, in the context of two-sided platforms, the concept is more cumbersome to implement. In Section III, we address fundamental challenges that come along with applying market definition on two-sided platforms. In Section IV, we consider two issues on the proper role of market definition that are conceptually intertwined and that underlie our position on the correct market definition in the context of two-sided markets.

12 The Notice does discuss primary and secondary markets as an instance of (connected) markets where constraints on substitution imposed by conditions in one market have to be considered for the definition of the connected market definition. See Market Definition Notice, cited supra note 6, para 56. Given the complementarity of the products offered on the respective markets, the relationship between primary and secondary markets may appear similar to that of the markets to which two-sided platforms cater. Note, however, that this complementarity is of a different kind in both scenarios, in particular as two-sided platforms offer their services to different user groups that are linked through cross-group network effects. Therefore, the role of network effects is the key to understanding the market realities in the case of twosided platforms. In light of this, questions of market definition also present themselves differently than in the context of primary and secondary markets.

13 On 3 April 2020 the Commission published an evaluation roadmap. See https://ec.europa.eu/info/law/betterregulation/have-your-say/initiatives/12325-Evaluation-of-the-Commission-Notice-on-market-definition-inEU-competition-law (accessed 21 Sept. 2020). A consultation period has been running since 26 June 2020. See https://ec.europa.eu/info/law/better-regulation/have-your-say/initiatives/12325-Evaluation-ofthe-Commission-Notice-on-market-definition-in-EU-competition-law/public-consultation (accessed 21 Sept. 2020). The Commission will publish its evaluation results in 2021 and plans to adopt a reformed Market Definition Notice in 2022.20 https://ec.europa.eu/competition/antitrust/legislation/timeline_table_M_AT_final.pdf (accessed 23 Dec. 2020).

14 See https://ec.europa.eu/commission/presscorner/detail/en/IP_20_1564 (accessed 21 Sept. 2020).

15 See Commissioner Vestager's speech "The future of EU merger control", 11 Sept. 2020, https://ec.europa.eu/commission/commissioners/2019-2024/vestager/announcements/future-eu-mergercontrol en (accessed 21 Sept. 2020).

${ }^{16} \mathrm{COM}(2020) 842$ final, Proposal for a Regulation of the European Parliament and of the Council on contestable and fair markets in the digital sector (Digital Markets Act). 
First, we explain why in such a context the calculation of market shares is less informative as a proxy for market power. Second, we argue that market definition must not (conclusively) determine the scope of a competition analysis. In Section $V$ we conclude.

\section{Why the Commission is right to attach importance to market definition in (digital) platform markets}

In their report on "Competition Policy for the Digital Era", commissioned by Competition Commissioner Vestager, the authors Crémer, de Montjoye and Schweitzer do not call the instrument of market definition as such into question, but state that:

in the case of platforms, the interdependence of the markets becomes a crucial part of the analysis whereas the role of market definition traditionally has been to isolate problems. Therefore ... less emphasis should be put on the market definition part of the analysis, and more importance attributed to the theories of harm and identification of anti-competitive strategies. ${ }^{17}$

The premise of this statement should indeed not be controversial: how competition analysis can do justice to the interdependencies between the effects certain market conduct has on the different user groups of two-sided platforms is one of the key challenges the digital era poses to competition law. The questions, however, of how much emphasis should be placed on market definition and, particularly, how much resources should be devoted to it in competition enforcement by courts and authorities, has to be put in perspective.

First of all, as we will discuss more in detail in the next section, ${ }^{18}$ it is true that the established methodologies for defining markets need to be adapted when applied to two-sided markets. Market definition in the context of two-sided platforms is more complex and cumbersome, and consumes more resources. Consequently, its results are more prone to error and, what is more, the simple statistics that are derived after defining the market become less informative for the competition analysis. In particular, market shares are less meaningful as an indicator of a two-sided platform's market power, the assessment of which is an essential element in merger control, ${ }^{19}$ in abuse cases, ${ }^{20}$ and when appraising the anti-competitive effects of an agreement. ${ }^{21}$ This is because the said interdependencies between different user groups have to be taken into account and can, depending on the facts of the individual case, lead both to a situation where high market shares cannot be regarded as an indicator of a high degree of market power and to a situation where a platform should be regarded as having a high degree of market power even if it has only a relatively low market share on this "market side". ${ }^{22}$ These findings especially call into question intervention thresholds based on market share.

\footnotetext{
${ }^{17}$ Crémer, de Montjoye and Schweitzer, Competition policy for the digital era (2019), p. 46 (emphasis added).

18 See infra section III.

${ }^{19}$ See Arts 2(2) and (3) of the EC Merger Regulation.

20 See Art. 102 TFEU, which applies to "undertakings of a dominant position within the internal market".

${ }^{21}$ See European Commission, Guidelines on the applicability of Article 101 of the Treaty on the Functioning of the European Union to horizontal co-operation agreements, O.J. $2011 \mathrm{C} \mathrm{11/01,} \mathrm{para} \mathrm{28.} \mathrm{In} \mathrm{contrast,} \mathrm{compe-}$ tition authorities and plaintiff parties are spared from assessing market power if agreements can be regarded as having by their very nature the potential to restrict competition and, therefore, are categorized as restrictions of competition "by object" pursuant to Art. 101(1) TFEU. See, e.g., Case C-235/92 P, Montecatini v. Commission, EU:C:1999:362, para 132.

${ }^{22}$ See infra section IV.1.
} 
Furthermore, the rise of (two-sided) digital platforms poses the challenge for competition authorities of identifying cross-market anti-competitive strategies that are new or appear to be less relevant in other contexts. Just to name two examples: the Commission's Google Shopping decision ${ }^{23}$ could prove to be a catalyst for the development of a doctrine of abusive "self-preferencing", the scope of which is mainly seen in the area of two-sided digital platforms. The concentration processes in the digital sector have fuelled the discussion over whether merger control should pay much closer attention to acquisitions that cut off potential competition. ${ }^{24}$

Against this background it becomes clear that competition analysis in relation to two-sided (digital) platforms needs flexible thinking that must not be limited from the outset by conventional ideas of market definition and market power assessment. Thus, the introductory quote by Crémer et al. is indeed convincing when taking the position of a competition authority that observes the potentially anti-competitive conduct of a platform or that has to assess a merger that involves one or several platforms. In such constellations, it typically does not seem reasonable to commence the investigation by devoting resources to a detailed and well-founded market definition. Market definition is inappropriate as a screening device or a first filter to identify competition problems with two-sided platforms. Instead, a competition authority is usually well advised to concentrate its resources on the analysis of theories of harm and an identification of possible anti-competitive strategies.

The picture changes, however, as soon as it is taken into account that market definition is in many cases mandatory for the application of EU competition law. Moreover, it is in particular the courts that are faced with competition cases - whether by way of judicial review of decisions of competition authorities or by way of private litigation - that benefit from a better transparency of the competition analysis and a clearer focus on the key arguments that go hand in hand with market definition. Viewed from this angle, the finding that market definition is more complex, error-prone and possibly less informative in the case of two-sided platforms may indeed lead to quite the opposite conclusion to the one stated above: the (correct) application and interpretation of market definition on two-sided platforms requires special diligence and attention.

\section{The positivist angle: EU competition law requires to define markets}

A competition law system might entirely dispense with defining markets. In particular, economic instruments make it possible to measure market power directly. Whether such a system is preferable in terms of administrability, implementation costs, error costs, legal certainty etc. ${ }^{25}$ appears to be doubtful but may remain open at this point. The practical relevance of

\footnotetext{
${ }^{23}$ Case AT.39740 Google Search (Shopping). An appeal is pending before the General Court (Case T-612/17 Google and Alphabet v. Commission).

${ }^{24}$ Motta and Peitz, "Removal of potential competitors - A blind spot of merger policy?", 6 Competition Law \& Policy Debate (2020), 19-25.

${ }^{25}$ An abandonment of the concept of market definition has been suggested, in particular, by Kaplow, "Why (ever) define markets?", 124 Harv. L. Rev. (2010), 437-517; Kaplow, "Market definition: Impossible and counterproductive", 79 Antitrust L.J. (2013), 361-379; Markovits, "Why one should never define markets or use market-oriented approaches to analyze the legality of business conduct under U.S. antitrust law: My arguments and a critique of Professor Kaplow's", 57 Antitrust Bull. (2012), 747-885. For a defence of the concept (though not necessarily as a mandatory element of competition analysis) see, e.g., Cameron, Glick and Mangum, "Good riddance to market definition?", 57 Antitrust Bull. (2012), 719-746; Keyte and
} 
market definition as a concept of EU competition law becomes obvious by the fact that it is not only widely used by courts and authorities, but considered practically mandatory in various contexts, ${ }^{26}$ in particular where market power has to be measured in order to determine whether or not:

- agreements between undertakings give rise to restrictive effects on competition pursuant to Article 101(1) TFEU, ${ }^{27}$ and whether these effects are appreciable; ${ }^{28}$

- agreements between undertakings afford these undertakings the possibility of eliminating competition in respect of a substantial part of the production in question and thus are prohibited even though they fulfil the other requirements of an exemption under Article 101(3) TFEU;29

- an undertaking is below the market-share thresholds that define the scope of application of block exemption regulations; ${ }^{30}$

- an undertaking is market-dominant pursuant to Article 102 TFEU; 31

- a concentration would (not) significantly impede effective competition, in the common market or in a substantial part of it, in particular as a result of the creation or a strengthening of a dominant position pursuant to Article 2(2) and (3) EC Merger Regulation. ${ }^{32}$

Even if market definition is more complex and less informative in cases involving two-sided platforms, it seems rather unlikely that the ECJ will shift away from requiring it where it considers it mandatory in non-platform cases. Thus, while defining relevant markets is for good reasons not at the beginning of an investigation that concerns a (digital) two-sided platform, to make a decision watertight, courts and authorities will ultimately have to define the relevant markets at least in those contexts in which the ECJ has repeatedly considered it a necessary element of a competition law analysis. ${ }^{33}$

Schwartz, "'Hally-Ho!': UPP and the 2010 Horizontal Merger Guidelines", 77 Antitrust L.J. (2011), 587650; Nevo, Definition of the Relevant Market: (Lack of) Harmony between Industrial Economics and Competition Law (Intersentia, 2015), p. 262; Hahne, op. cit. supra note 5, pp. 268-283.

${ }^{26}$ For a detailed analysis see Sousa Ferro, op. cit. supra note 1, pp. 56-91; Hahne, op. cit. supra note 5, pp. 6166 and 189-220.

${ }_{27}$ See European Commission, Guidelines on the applicability of Article 101 of the Treaty on the Functioning of the European Union to horizontal co-operation agreements. O.J. 2011 C 11/01, para 28.

${ }^{28}$ See European Commission, Notice on agreements of minor importance which do not appreciably restrict competition under Article 101(1) of the Treaty on the Functioning of the European Union (De Minimis Notice). O.J. 2014 C 291/01, para 8.

29 See, e.g., Case T-395/94, Atlantic Container Line and Others v. Commission, EU:T:2002:49, para 300.

30 See, e.g., Art. 3 of the Commission Regulation (EU) No 330/2010 of 20 April 2010 on the application of Article 101(3) TFEU to categories of vertical agreements and concerted practices. O.J. $2010 \mathrm{~L} 102 / 1$.

31 Case C-85/76, Hoffmann-La Roche v. Commission, EU:C:1979:36, para 21; Case T-62/98, Volkswagen v. Commission, para 230; Case T-61/99, Adriatica di Navigazione v. Commission, EU:T:2003:335, para 27; European Commission, Dec. 2005, DG Competition discussion paper on the application of Article 82 of the Treaty to exclusionary practices, para 11.

32 Case C-68/94, France and Société commerciale des potasses and de l'azote and Entreprise minière and chimique v. Commission, EU:C:1998:148, para 143; Case T-342/99, Airtours v. Commission, EU:T:2004:192, para 19; Case T-151/05, NVV and Others v. Commission, EU:T:2009:144, para 51; Case T-399/16, CK Telecoms UK Investments v. Commission, EU:T:2020:217, paras 144-145. See also European Commission, Guidelines on the assessment of horizontal mergers under the Council Regulation on the control of concentrations between undertakings, O.J. 2004 C 31/5, para 10.

${ }^{33}$ Certainly, an ultimate market definition must not be given where different (plausible) definitions lead to the same outcome. See, e.g., Case M.4731, Google/Doubleclick, paras 44-56 (Commission left open whether 


\section{On the jurisprudential function of market definition and why the Commission should be concerned about it}

To include market definition as a formal step in a competition analysis, thereby combining an approach structured and defined by law with economic methods, forces those who invoke and enforce competition law to carefully consider, interpret and (verbally) explain when and to what extent substitution may restrict a firm's market power. This not only disciplines competition authorities or parties that carry out and put forward a competition analysis before a court but makes their arguments more transparent to the parties affected by a decision, the opposing parties in private litigation and, last but not least, the courts that have to review an authority's decision or to judge in dispute between private parties. Thus, not only can the requirement to define markets make competition practice more transparent and predictable to the firms concerned; it also facilitates the work of the courts and, consequently, may help to avoid judicial errors and improve the effectiveness of judicial redress.

This is not to say that the direct application of economic methods to substantiate a theory of harm would necessarily lead to greater legal uncertainty. ${ }^{34}$ But including market definition in an analysis may help courts to review cases more efficiently, because it may limit from the start the theories of harm and countervailing efficiency effects that might be put forward by the parties. Consequently, one may indeed assume that, insofar as market definition was postulated by the courts as a necessary prerequisite for the application of EU competition law, this was done in order to guarantee legal certainty and to facilitate judicial review. ${ }^{35}$ This rationale would be missed if there were no legal clarification of those (fundamental) issues that market definition raises in the case of two-sided platforms.

This leads to the question of why the Commission in particular should take on this task. Since, after all, while the Commission itself, when exercising its discretion, is bound by the rules it has laid down in the Market Definition Notice, ${ }^{36}$ it is the ECJ that has the last word on the interpretation of the EU competition provisions. One could therefore assume that the clarification of legal issues regarding market definition lies anyway in the hands of the European courts or, indirectly, the national courts as they can initiate preliminary references to the ECJ. ${ }^{37}$

Analysis of the European courts' adjudication on market definition has revealed that the Court of Justice and the General Court tend to attach great importance to the Commission's statements in the Market Definition Notice. ${ }^{38}$ There should be no doubt that, as a matter of principle, the rules on market definition as developed and applied by the Commission should be subject to full judicial review. It is otherwise only for their actual implementation, insofar ${ }^{39}$

search and non-search advertising have to be considered separate markets); Case M.7217, Facebook/WhatsApp, para 79 (Commission left open whether segments of the market for online advertising constituted relevant product markets in their own right).

${ }^{34}$ See Hahne, op. cit. supra note 5, pp. 252-257.

35 See Sousa Ferro, op. cit. supra note 1, p. 30.

${ }^{36}$ Case T-210/01, General Electric v. Commission, EU:T:2005:456, para 516; Sousa Ferro, op. cit. supra note 1, pp. 51-52.

37 Art. 267 TFEU.

38 See Sousa Ferro, op. cit. supra note 1, pp. 52-55.

${ }^{39}$ See Sousa Ferro, "Judicial review: Do European courts care about market definition?", 6 JECLAP (2015), 400410 , at 410 ("[W]hile market definition theory may be highly complex, its practical application and the 
as it involves complex economic assessments. ${ }^{40}$ Yet, as one observer noted, "[o]ne is hard pressed to find a case, since the [General Court] was created, with any level of substantial analysis of [market definition] by the ECJ". ${ }^{41}$ This indicates that the Commission's 1997Notice was a truthful codification of the Court's preceding adjudication and that the Commission's positions on the legal issues ${ }^{42}$ of market definition were barely challenged by the parties and, thus, seem to have been essentially undisputed. This leaves us with the - admittedly somewhat trivial - insight that a careful analysis of the questions of law involved with market definition on part of the Commission provides valuable guidance to the European Courts and saves judicial resources.

Further, it must not be ignored that the Commission enjoys a special position vis-à-vis the national courts and authorities: while the latter are not bound by guidelines, notices and other soft law instruments, ${ }^{43}$ they are bound by the Commission's decision-making practice in the circumstances covered by Article 16 of Regulation 1/2003. In fact, Member State courts ${ }^{44}$ and authorities ${ }^{45}$ often seem to regard it as an obvious option to follow the Commission's view as expressed in its soft law instruments without further ado. ${ }^{46}$ Thus, the distinguished position of the Commission ${ }^{47}$ should be seen also as entailing a particular responsibility to provide guidance on the legal rules that govern market definition in EU competition law.

Finally, it should not be forgotten that the Commission has comparatively great expertise and considerable resources at its disposal. Certainly, this also involves a wide range of tasks. But the Commission, when considering how to use its resources, should not underestimate the crucial importance of the positive externalities it may create to the benefit of the national

specific issues raised before Courts usually do not require complex assessments of an economic nature. The majority of market definitions are not based on complex economic data, but are instead build on facts, opinions, and logic").

40 The ECJ traditionally exercises only a limited review with regard to complex economic appraisals. See, e.g., Case C-42/84, Remia v. Commission, EU:C:1985:327, para 34; Case C-142/83, BAT Reynolds v. Commission, EU:C:1987:490, para 62.

41 Sousa Ferro, op. cit. supra note 39, at 407.

42 The Commission's implementation of market definition, i.e. its fact-finding and interpretation of facts, has been challenged in various instances. See, e.g., Case T-342/07, Ryanair v. Commission, EU:T:2010:280, paras 95-117.

43 But note the Grimaldi doctrine, according to which the Member States' courts when adjudicating on EU law must consider recommendations issued by the EU institutions "in particular . . . where they are designed to supplement binding Community provisions". Case C-322/88, Grimaldi v. Fonds des maladies professionnelles, EU:C:1989:646, para 18. See on the development, scope and impact of the doctrine Korkeaaho, "National courts and European soft law: Is Grimaldi still good law?", 37 YEL (2018), 470-495.

44 There seems to be no research with a focus on the Market Definition Notice's impact on the jurisprudence of Member States' courts. The reception of five other competition-related soft law instruments issued by the Commission is analysed in Georgieva, "The judicial reception of competition soft law in the Netherlands and the UK", 12 ECJ (2016), 54-86.

${ }^{45}$ A certain reluctance on part of a national competition authority to develop its own position on market definition in the digitized economy has been noted, for instance, in Kováčiková, "A definition of digital markets by the Slovak Antimonopoly Office - Has the boat to digitalisation already sailed?", 13(21) Yearbook of Antitrust and Regulatory Studies (2020), 247-258, at 256, which, after analysing market definition in three decisions by the Slovak Antimonopoly Office, concluded that "courage to launch an expert discussion and apply new tests to explore and assess the digital market is still lacking".

46 Hence, one should only assume with caution that the use of EU soft law instruments would preserve Member States' autonomy and guarantee flexibility and diversity of national regulatory approaches. See Korkeaaho, "EU soft law in domestic legal systems: Flexibility and diversity guaranteed?", 16 MJ (2009), 271290.

47 See Ackermann "European competition law" in Riesenhuber (Ed.), European Legal Methodology (Intersentia, 2017), pp. 513-535, at p. 520 ("the Commission ... has therefore grown into the role of an authentic interpreter of competition rules"). 
courts and authorities by elaborating and publishing its own legal position on market definition in the platform economy.

\section{Avoiding the need for amendments to competition law and new ex ante regula- tion}

Clarifying the necessary adaptations for market definition is essential to facilitate the application of traditional competition law instruments to two-sided platforms. This, in turn, may contribute to making it avoidable to amend competition law or to reducing the scope of new ex ante regulation.

For instance, the Commission's initiative for ex ante regulation through a "Digital Markets Act" 48 is motivated by the belief that current EU competition law is inadequate to protect functioning competition in digital markets. This view is based only to some extent on clear-cut limits to competition enforcement when dealing with two-sided (digital) platforms. As far as the substance of competition law is at stake, it is mainly based on considerable uncertainties as to its actual scope and problems of implementation - including uncertainties concerning an adequate application of the established methods of market definition. ${ }^{49}$

Such uncertainties have also tempted Member States' legislatures to expand national competition law or to regulate at national level. Certain legislative measures in Germany may illustrate this point. Under the recent reform of the German Competition Act, on the one hand, the legislature integrated the concept of "intermediation power" into the market dominance test. ${ }^{50}$ This amendment aims to make it easier to subject operators of two-sided platforms to the general prohibition of abusive conduct, ${ }^{51}$ possibly even if their market shares among users on one "market side" may well be below the threshold above which dominance usually is considered conceivable. On the other hand, the legislature introduced a new regime under which the German competition authority, the Bundeskartellamt, has been given the power to formally establish that an undertaking is of "paramount significance for competition across markets." ${ }^{2}$ Based thereon, undertakings can then be subject to the prohibition of certain listed practices in markets they do not dominate. ${ }^{53}$ The legislator justified this with, among other things, the insight that market definition in digital markets plays a less important role for competition analysis. ${ }^{54}$ Independently of these reforms of the Competition Act, the German legislature has established a right for payment service providers and e-money issuers to access technical infrastructure that contributes to mobile and internet-based payment

\footnotetext{
${ }^{48}$ Cited supra note 16.

${ }^{49}$ See European Commission, "Digital Markets Act - Impact assessment support study", executive summary and synthesis report (Dec. 2020), p. 17 ("Meanwhile, competition law is not always an ideal solution due to challenges in applying the market definition concept in multi-sided markets"). See also, in view of potential advantages through remedies (including possibly market-wide rule making) by way of a (then) contemplated comprehensive market investigation instrument, Schweitzer, "The New Competition Tool: Its institutional set-up and procedural design", expert report prepared for the European Commission (2020), pp. 24-25.

50 Section 18(3b) of the Competition Act (Gesetz gegen Wettbewerbsbeschränkungen).

51 Section 19 of the Competition Act (Gesetz gegen Wettbewerbsbeschränkungen).

52 Section 19a(1) of the Competition Act (Gesetz gegen Wettbewerbsbeschränkungen).

${ }^{53}$ Section $19 \mathrm{a}(2)$ of the Competition Act (Gesetz gegen Wettbewerbsbeschränkungen).

54 Deutscher Bundestag, BT-Drucksache 19/25868, p. 113.
} 
services. ${ }^{55}$ One reason for this regulatory intervention - although certainly not the only one ${ }^{56}$ - was that it appeared to be uncertain whether Apple, as the operator of mobile devices, could be regarded an addressee of Article 102 TFEU (or the equivalent provision under German competition law). That depends in particular on the question of how the power that a platform derives from a multi-homing/single-homing framework ("competitive bottleneck" ${ }^{77}$ ) is considered within the market definition framework. ${ }^{58}$

Certainly, there is nothing wrong in adjusting competition laws to new challenges not only incrementally by case law but also by way of legislation. And, where competition law fails to ensure competitive outcomes, it may be necessary to regulate. Yet, the introduction of new concepts in competition laws and new ex ante regulation comes at a price. Apart from the immediate expenditure of legislation, it creates (new) legal uncertainty and is prone to error, in particular as it may overstep the mark. Moreover, national measures, in particular by way of ex ante regulation, lead to fragmentation within the internal market and, therefore, will typically in any case trigger a political debate on harmonizing legislation at Union level. That is why such (national) legislative initiatives should be considered the result of a balancing exercise that also includes the said cost factors. Therefore, by outlining how the concept of market definition has to be implemented on two-sided platforms, the Commission may contribute to clarifying the scope of EU competition law and, thus, may help to avoid or to tailor more precisely the expansions of national competition law or new ex ante regulation that is meant as a response to a level of competition enforcement that is allegedly too low or too uncertain.

\section{Major challenges posed by the two-sidedness of platforms and how to cope with them}

To define markets, one has to identify the goods and services offered by an undertaking and to understand substitute offers. This is more challenging in the case of two-sided platforms as they typically offer complex and interrelated products. In the following, we address five key issues.

\section{Single-market approach vs. multi-markets approach}

In the context of a two-sided platform, one approach is to define a market for each side. Consequently, each of the two markets can be analysed separately while taking into account that they are linked through cross-group network effects. This is referred to as the "multimarkets approach". Alternatively, one may define a single market for an intermediation service offered to both sides of the market. This is referred to as the "single-market approach".

\footnotetext{
${ }^{55}$ Section 58a of the German Payment Services Supervisory Act (PSSA). See Franck and Linardatos, "Germany's 'Lex Apple Pay': Payment Services Regulation overtakes competition enforcement”, JECLAP (forthcoming).

${ }^{56}$ Further, it is unclear whether and under which conditions a doctrine of abusive "self-preferencing" provides a right of access beyond the conventional "refusal to supply" doctrine, which is characterized by a high intervention threshold, requiring in particular that a facility (such as a platform) be indispensable for entering a neighbouring market so that a refusal to grant access would be likely to eliminate all competition in this market. See from the EU adjudication Case C-7/97, Bronner, EU:C:1998:569, para 41; Case C241/91 P and C-242/91, P RTE and ITP v. Commission (“Magill"), EU:C:1995:98, para 56.

57 The term was coined by Armstrong, "Competition in two-sided markets", 37 Rand Journal of Economics (2006), 668-691.

58 See infra section III.3.b).
} 

tems

The Commission and the EU courts had to consider this issue with regard to payment card systems. ${ }^{59}$ In the MasterCard case, the General Court rejected the applicants' view that there was only one product market at issue, namely a market where the payment card systems provided a single service offered to both cardholders and merchants and where they competed against each other and against all other forms of payment. Thus, the General Court confirmed the Commission's view that the "issuing side" and the "acquiring side" should be considered separate markets ${ }^{60}$ and reinforced this position in a subsequent judgment involving the French payment card system Cartes Bancaires. ${ }^{61}$

In Cartes Bancaires, the ECJ held that such a definition of separate issuing and acquiring markets must not, however, have the effect that interdependencies with the "acquiring side" of the payment system had to be excluded from the analysis of agreements on the "issuer side". The Court stressed that network effects between the two user groups must be taken into account when assessing whether the payment system's restrictions on the issuing of cards should be regarded as a restriction of competition by object or effect under Article 101(1) TFEU.62 To reach this conclusion, the ECJ did not take an explicit stand on the applicability of the multi-markets approach as such. The judgment is most crucial, however, because it clarifies in any case that doing justice to the interrelation between the different sides of a two-sided platform does not require adopting a single-market approach. Thus, the Court implicitly accepted the multi-markets approach under the condition that cross-group network effects are considered for the definition of the markets on the two sides of the platform and at subsequent stages of a competition law analysis.

\section{b) On the (in)adequacy of a single-market approach in the case of matching platforms}

While the Commission in recent years has dealt with quite a number of cases that involved two-sided digital platforms, it appears that in none of these cases did the Commission explicitly engage in a discussion on the question of the conditions under which a multi-markets approach or a single-market approach should be applied. Yet the Commission's practice indicates that it analyses these cases based on a multi-markets-approach throughout. First of all, in various cases the Commission defined separate markets for online advertising and user content. ${ }^{63}$ In all those decisions, the application of a multi-markets approach does not seem to have been in dispute. ${ }^{64}$ This approach is, however, considered more controversially

\footnotetext{
59 See Sousa Ferro, op. cit. supra note 1, pp. 252-255.

${ }^{60}$ Case T-111/08, MasterCard, EU:T:2012:260, paras 174-177. On appeal, market definition was not challenged and, therefore, not addressed by the ECJ. Case C-382/12 P, MasterCard, EU:C:2014:2201, para 178.

${ }^{61}$ Case T-491/07, RENV - CB v. Commission, EU:T:2016:379, paras 79-80.

62 Case C-67/13 P, Groupement des cartes bancaires, EU:C:2014:2204, paras 77-79.

${ }^{63}$ See, e.g., Case M.5727, Microsoft/Yahoo! Search Business, paras 61-81 (online advertising) and paras 85-86 (internet search); Case M.7217, Facebook/WhatsApp, para 34 (consumer communications services), para 61 (social networking services) and para 79 (online advertising); Case M.8124, Microsoft/Linkedln, paras 74-83 (enterprise communications services), paras 87-117 (professional social networks), paras 126-147 (online recruitment services) and paras 152-161 (online advertising services).

${ }^{64}$ But cf. Broos and Ramos, "Competing business models and two-sidedness: An application to the Google Shopping case", 62 Antitrust Bulletin (2017), 382-399, which argues that, in the case of Google, search market and advertising market should not be separated since Google charges neither the consumers for searching nor the advertisers for advertising per se but only for transactions ("per click"). This claim is,
} 
as regards so-called "matching platforms", i.e. platforms that facilitate transactions such as payment card systems, online marketplaces, hotel booking or real-estate platforms, or platforms that enable a different kind of interaction, for instance online dating platforms. ${ }^{65}$ Most prominently, the U.S. Supreme Court in Ohio v American Express Co. argued that "two-sided transaction platforms, like the credit-card market . . . facilitate a single, simultaneous transaction between parties" and, consequently, adopted a single-market approach. ${ }^{66}$ The UK's Competition and Markets Authority stipulated in a merger decision that involved two online food ordering platforms that "where the platform is 'matching' or facilitating transactions . . . a single market definition is appropriate, which takes account of the competitive constraints on both sides of the market". 67

The Commission has taken a different route in its practice on payment card systems ${ }^{68}$ and in particular its reasoning for the definition of a distinct market for comparison shopping services in Google Search (Shopping) also reveals the use of a multi-markets logic in the context of online platforms. Most notably, when delineating comparison shopping services from merchant platforms from a demand side perspective, the Commission did not presume a single intermediation service offered to two user groups, but distinguished between the users' perspective and the online retailers' perspective, and gave separate reasons why it assumes that comparison shopping services and merchant platforms serve a different purpose. ${ }^{69}$ Given this differentiated reasoning, it would have been desirable for the Commission to have also stated clearly that, correspondingly, two interrelated markets can be distinguished: one in which Google Shopping offers consumers a service to find products they may be interested in, and another one where it offers sellers a listing service that helps them to reach consumers.

A view on the practice of the Member States' authorities and courts reveals a considerable heterogeneity as to the right approach in case of matching platforms. After the Netherlands Competition Authority, in a 2007 merger case that involved two horticultural platforms, opted for a single-market approach, ${ }^{70}$ it was most notably the Bundeskartellamt that explicitly considered the issue. As a matter of principle, the authority assumes that separate product mar-

however, dubious since it would mean that market definition was dependent on the used price instruments. Based on this concept, in the case of a platform such as Airbnb, which charges only for completed bookings, the single-market approach would also need to be followed. In contrast, a multi-markets approach is required in the case of a platform such as HomeAway, a competitor of Airbnb in many regional markets, which used to charge listing fees for short-term rental accommodation. Both firms could then apparently not be attributed to the same market. However, as a property can be rented out via HomeAway or via Airbnb, the market definition would then not adequately reflect demand-side substitutability and the competitive restraints a platform faces and, thus, would not fulfil its designated function as an instrument of competition law.

65 Note, however, that the Commission's reasoning in the merger case Travelport/Worldspan (Case M.4523), where it described the relevant market as a "market for electronic travel distribution services through a [global distribution service]", has been interpreted, for example, by the Bundeskartellamt as following a single-market logic, although it was acknowledged that "[t]he intermediary service as a product, i.e. the matching by the platform, is not considered in the context of market definition". Bundeskartellamt, "Market power of platforms and networks", Working Paper B6-113/15 (2016), p. 27.

66 Ohio v. American Express Co, 585 U.S. _ (25 June 2018), slip opinion pp. 13-15.

67 Competition and Markets Authority, 16 Nov. 2017, Just Eat and Hungryhouse, para 4.11.

${ }^{68}$ Case COMP/29.373, Visa International - Multilateral Interchange Fees, para 43; Case COMP/34.579, MasterCard, COMP/36.518, EuroCommerce, COMP/38.580, Commercial Cards, paras 283-329.

${ }^{69}$ Case AT.39740, Google Search (Shopping), paras 216-223.

70 Nederlandse Mededingingsautoriteit 5901/184 Bloemenveiling Aaslmeer - Flora Holland. 
kets for each side of a platform should be defined. However, in the case of matching platforms the Bundeskartellamt regards a single-market approach as feasible if "user groups essentially have the same need for liaising with the respective other group, and therefore, the groups' views regarding substitutability of function do not differ substantially". ${ }^{71}$ On that basis, the Bundeskartellamt assumed, for example, with a view on Amazon's online marketplace that the possibilities to substitute may be more limited for retailers than for consumers, who want to shop and who could switch to competing retailers (online and offline). ${ }^{72}$ This suggests separate markets for the provision of online marketplace services to retailers, on the one hand, and, on the other hand, to the consumers. ${ }^{73}$ In the same vein, the National Commission of Markets and Competition (CNMC) in Spain opted for a multi-markets approach in a merger case that involved online food ordering platforms. The CNMC assumed in particular different freedoms for consumers and restaurants to bypass the intermediation services offered by these platforms: ${ }^{74}$ while the former could readily directly contact the restaurants that offered to deliver food, the latter were dependent on the intermediary services of the platforms to gain access to their customers. Consequently, the authority defined, first, a market where the online platforms offered their intermediation services to restaurants and, second, a market where consumers could order food with delivery service both via the ordering platforms and directly from restaurants. ${ }^{75}$

Yet, the Bundeskartellamt either adopted a single-market approach or considered such an approach at least feasible in merger cases that involved online dating platforms ${ }^{76}$ online comparison platforms ${ }^{77}$ and real-estate platforms. ${ }^{78}$ The Autorité de la concurrence, the French competition authority, referred to this latter decision when it also applied a singlemarket approach in a merger decision that involved real-estate platforms. ${ }^{79}$ It is remarkable

\footnotetext{
71 Bundeskartellamt, cited supra note 65, p. 28.

72 lbid., pp. 31-32.

73 The Bundeskartellamt closed its abuse proceedings after Amazon amended its terms of business for sellers on its European online marketplaces. In its case summary, the authority stated that it was "inclined to assume a product market for online marketplace services", stressing that "Amazon's significance as a 'gate-keeper' for customer access is high due to its large customer base, some of which use the Amazon marketplace either primarily or exclusively for their purchases." 17 July 2019, B2-88/18, Case Summary, p. 10.
}

${ }^{74}$ See, by contrast, the Netherlands Authority for Consumers and Markets' approach in a case that concerned the use of narrow price parity clauses imposed by the online food ordering platform "Thuisbezorgd.nl" on the restaurants. Without taking an ultimate stand on market definition, the Dutch authority rejected "speak[ing] of 'a possible market for online food ordering platforms', because it is clear that online platforms compete with the direct sales channels of restaurants/restaurant chains". Instead, the authority assumed that there "could be 'a possible market for delivered meals' or 'a possible market for delivered and takeaway meals." 18 Nov. 2016, ACM/DM/2016/207286, Case no 15.1073.53, para 37 (references omitted). The authority thus suggested a symmetrical (relative) independence of both the restaurants and the consumers from the online food ordering platforms' intermediation services.

75 Comisión Nacional de los Mercados y la Competencia, 31 Mar. 2016, C/0730/16 Just Eat/La Nevera Roja, paras 26-37.

76 Bundeskartellamt, 22 Oct. 2015, B6-57/15, Parship/Elitepartner, paras 71, 75-78; case summary, p. 2.

77 Bundeskartellamt, 24 July 2015, B8-76/15, Verivox/ProSiebenSat1, case summary, p. 2.

78 Bundeskartellamt, 20 Apr. 2015, B6-39/15, Immonet/Immowelt, case summary, p. 2.

79 Autorité de la concurrence. 1 Feb. 2018, Decision n 18-DCC-18, SeLoger/Logic-Immo, paras 20-29. Note, however, that the authority remarked (without further explanation) that "the delineation of separate markets for each of the sides of this market would not change the conclusions of the competitive analysis". It is also noteworthy that in its recent merger guidelines, although the authority mentions the adoption of a single-market approach in this decision, the explanations appear remarkably cautious as the authority does not establish general rules as to whether and when it prefers to apply a single-market approach in 
that the adoption of a single-market approach in these cases does not seem to be the result of a differentiated analysis of potential substitutes on both sides of the platform. ${ }^{80}$ Instead, the Bundeskartellamt put forward an "indivisibility" argument, essentially claiming that an intermediation service offered to two (or more) "market sides" could not be split up into two markets, as such a multi-markets approach could not fully do justice to the interdependencies of the "market sides". Moreover, the authority referred to the nature of the "matching platform" as it stipulated, for instance, in its decision involving online dating platforms, that the two user groups, i.e. men and women who are looking for a partner, would inevitably meet again if they switched to conceivable alternatives. ${ }^{81}$ This statement does, however, merely beg the question of the respective possibilities of men and women to do so without the use of an online dating platform. If, for example, men's and women's inclinations to use an online dating platform or user behaviour (e.g., the frequency of usage) is asymmetric, this will result in different possibilities of substitution. In particular, it is conceivable that there are specialized platforms where both groups are very asymmetrically distributed. Yet, when a user considers switching from a platform with an imbalanced gender ratio to one with a balanced gender ratio, this implies that the attractiveness of such a switch is likely to depend on the user's gender. Certainly, online dating platforms may have a self-interest in achieving a balanced gender ratio, and there are instruments available that may be used for this purpose, such as advertisements that specifically target one user group, or an adaptation of the price structure for using the service. But, then again, it seems rather doubtful to assume without hesitation that there are equal opportunities to substitute. ${ }^{82}$

Furthermore, one must not ignore that different people may use a matching platform for different purposes and with different intensity; thus, a platform seen as a good substitute by some may be seen as a bad substitute by others and there may be systematic differences between the two sides. Also, users on one side may typically be active on multiple platforms, while users on the other side may be active only on one; this will affect substitution possibili-

the case of matching platforms. Autorité de la concurrence, Lignes directrices de l'Autorité de la concurrence relatives au contrôle des concentrations (2020), para 599.

80 This appears to be different with the judgment of the Court of Amsterdam in an abuse case involving a realestate platform. See Rechtbank Amsterdam, 21 Mar. 2018, NL:RBAMAS:2018:1654, VBO Makelaar v. Funda en NVM. While the Court's rhetoric indicates that it assumed a single-market approach ("The experts defined the relevant market as the market for housing websites in the Netherlands." Ibid., at para 2.6), one of the economists who acted as a court expert in the case stressed that "[a]s funda was a "twosided platform .... the experts considered potential substitutes and competitive constraints on both sides". See Niels, "Funda-mentals of Article 102: a dominant platform, but not abuse", OxeraAgenda, Sept. 2018, p. 2. On appeal, the Gerechtshof Amsterdam did not further elaborate on market definition and confirmed the first instance decision in this respect. 26 May 2020, NL:GHAMS:2019:772, para 3.6.

81 Bundeskartellamt, 22 Oct. 2015, B6-57/15, Parship/Elitepartner, para 78; Case Summary, p. 2.

${ }^{82}$ As a proof of concept, consider a market environment in which two matching platforms operate offering services to two groups - e.g. men and women on heterosexual dating sites. Users are identified by their first name and other characteristics. Suppose that both platforms accept all men, but that platform 1 accepts women with a first name starting with a letter between $A$ and $K$ and platform 2 those with a first name starting with a letter between $L$ and $Z$. Thus, platforms are competing for men but not for women. In such a situation it is logically inconsistent to speak of a matching service offered by both platforms to all users since on the side of female users there no substitution possibilities exist. The multi-markets approach easily accommodates such an environment: there is one market for men, a market for women with a first name starting with a letter between $\mathrm{A}$ and $\mathrm{K}$ in which platform 1 operates as a monopolist and for women with a first name starting with a letter between $L$ and $Z$ in which platform 2 operates as a monopolist. Markets are linked through cross-group network effects. 
ties. The intermediary offers fundamentally different services to the two sides. ${ }^{83}$ It would be quite a coincidence if the substitution patterns were symmetric on both sides of the platform. ${ }^{84}$ What is more, competition analyses often draw on market prices or price changes, such as in the case of merger control by means of pricing pressure tests. But, if the prices differ between the respective user groups (as apparently in the case of online dating platforms), it remains unclear which is the single price that should be relied upon following the single-market approach.

This shows that, with regard to platforms that aim at brokering transactions between two user groups and even in the case of online dating platforms - which seem to many an obvious candidate for a single-market approach ${ }^{85}$ - it cannot simply be assumed that the competitive situation of the platform is symmetrical in relation to both user groups. But even if an investigation came to the conclusion that the two sides were symmetric (in terms of characteristics and the way the platform sets prices), the single-market approach does not offer any benefits over the multi-markets approach because the economic analysis of the latter could simply consider two identical markets that are characterized by symmetric cross-group network effects. However, symmetry may be observed in the status quo and disappear in a counterfactual, e.g. when evaluating the competitive effect of contractual restrictions imposed on users on one side. To study such effects in a meaningful way it would be necessary to use the multi-markets approach.

\section{c) Conclusions}

Competition authorities and courts are well advised to uniformly use a multi-markets approach when they define markets in the context of two-sided platforms. ${ }^{86}$ It would be desirable for the Commission to make this explicit with the reform of the Market Definition Notice.

The multi-markets approach is a logical and consistent application of demand-side substitutability to two-sided platforms as it naturally accounts for different substitution possibilities by the user groups on the two sides of a platform. It is based on the economic primitives of the market and not on derived constructs such as an overall demand for an intermediation service, which depends on demand substitutability on each side of the platform as well as on the cross-group network effects linking the two. ${ }^{87}$

While one might think of conditions under which a single-market approach could theoretically be feasible, the necessary conditions are so severe that it would only be applicable under specific circumstances. Moreover, to recognize that a single-market approach might be applicable under certain conditions would create substantial risks that an authority or a court

\footnotetext{
${ }^{83}$ To make this explicit for the case of dating sites, heterosexual men are simply not interested in the intermediation service offered to women; correspondingly, in the case of heterosexual women.

${ }^{84}$ Using the same web design and matching algorithm does not imply that substitution pattern is symmetric since, for example, the format chosen by the intermediary for how users of the two groups can exchange messages may be more attractive for members of one than for those of the other group.

85 See, for example, Crémer, de Montjoye and Schweitzer, op. cit. supra note 17, p. 46.

86 In this respect, our view is in line with Katz and Sallet, "Multisided platforms and antitrust enforcement", 127 Yale Law Journal (2018), 2142-2175, at 2153-2158 and Niels and Ralston, "Two-sided market definition: some common misunderstandings", ECJ (2021), DOI:10.1080/17441056.2020.1851478, at 10-11.

87 The latter would need to be derived from the demand functions of each of the two sides.
} 
would adopt it erroneously. This does not mean that the interactions between the different user groups that are served by a two-sided platform are to be neglected; quite the contrary: they must be considered for the definition of the (multiple) markets as they may be crucial to evaluate demand-side substitutability on each side of the platform.

\section{Markets without a price}

It is a widespread phenomenon that operators of two-sided platforms do not charge prices vis-à-vis one group of their customers: viewers may make use of free, ad-financed TV, consumers are not charged a (visible) price for the use of e-commerce platforms such as Amazon Marketplace or Booking, and Google charges no search fee for using its search engine and Facebook no membership or usage fee. ${ }^{88}$

a) Why do zero-price markets exist?

A number of economic considerations can explain why this is a rational and sustainable business strategy. First, it is important to see that, in the case of transaction platforms, the platform may decide to levy the fee entirely on the merchant side. Thus, while the consumers do not pay a visible fee, they bear part of the fee or even the entire fee as the merchant will pass it onto them through higher prices. Second, a platform may want to subsidize one side, which may lead to negative prices. ${ }^{89}$ However, such prices may be self-defeating if they attract unwanted types of users or are simply not feasible. In particular, "zero" prices are often a feature of two-sided platforms on the side that exerts a positive cross-group effect and experiences a negative from the other. Many ad-financed platforms such as commercial TV or internet news portals have this feature. In this case, consumers incur an opportunity cost in the form of their scarce attention, which is partly diverted to advertising. Another instance is that consumers "pay" with their data and the platform can use this data to improve services (which may even be a prerequisite for it to succeed) or offer alternative services that the platform or third parties can monetize (possibly with different consumers); in such instances it is possible but not always the case that consumers incur an opportunity cost for providing their data. Many ad-financed digital platforms benefit from the attention and data consumers provide. The data they receive allows them to provide better-targeted ads, which is in the interest of advertisers and, sometimes, also consumers. Furthermore, some platforms choose a "freemium" strategy, offering menus of contracts that include a base offer at "zero price", or they offer a "zero price" as part of a dynamic pricing strategy that builds up a sufficiently large user base to convince late arrivals that it is worth paying. Finally, "zero prices" may be forced by regulation. For example, net neutrality regulation ${ }^{90}$ can effectively restrict the freedom of internet service providers (ISPs) - which operate as two-sided platforms, enabling transac-

\footnotetext{
${ }^{88}$ Business models may change over time. For instance, YouTube started as a "free" ad-financed video streaming platform but recently added a subscription service.

89 This is a basic insight of the economic analysis of platform pricing; see Rochet and Tirole, "Two-sided markets: A progress report", 37 Rand Journal of Economics (2006), 645-667, and Armstrong, "Competition in twosided markets", 37 Rand Journal of Economics (2006), 668-691.

90 Under EU law, the principle of net neutrality is embodied in Art. 3 of Regulation (EU) 2015/2120 of the European Parliament and of the Council of 25 November 2015 laying down measures concerning open internet access and amending Directive 2002/22/EC on universal service and users' rights relating to electronic communications networks and services and Regulation (EU) No 531/2012 on roaming on public mobile communications networks within the Union. O.J. 2015, L 310/1.
} 
tions between content providers and consumers - to charge content providers for the delivery of content. ${ }^{91}$

b) Past EU competition practice: (unfounded) reluctance to define "viewers' markets"

A view on past EU competition practice reveals a certain reluctance on part of the European Commission to acknowledge that there can be a "market" that deserves consideration even if the observable transactions do not involve a monetary price. In some merger cases from the 1990s involving TV broadcasters, the Commission left open the question of whether there is a "broadcasting" or "viewers' market", arguing that

all tv broadcasters compete against each other for audience shares. However, in view of the fact that there is no direct trade relationship between broadcasters of "free" tv channels, on the "supply side" and, viewers on the "demand side," it might be argued that tv broadcasting does not constitute a market in the strict economic sense of this notion. ${ }^{92}$

The Commission suggested that it might not be necessary for the purposes of competition law to consider the "viewer's market" a "market" because, "[i]n any event, the audience shares in the TV broadcasting are a determinant factor for the success of the broadcasters in the TV advertising market and have, therefore, to be assessed at least in the context of this market. ${ }^{93}$ Thus, the Commission essentially reasoned that, as high shares in the market for TV viewers would translate into higher shares in the TV advertising market, it would in all probability not be decisive for the outcome of a merger case if the existence of a market for TV viewers were denied.

The underlying policy argument to legitimize this approach would seem to be that the interests that competition law is meant to protect are properly taken care of by focusing on those "sides" of a platform market where the monetization takes place. However, if we assume that competition law aims at protecting the economic interests of the consumers, to ignore the unpaid side is typically inappropriate. This can easily be illustrated with a view on commercial TV financed through advertising: if viewers dislike TV advertising (as evidence suggests), viewer demand will respond to changes in the level of advertising. A merger analysis would thus need to take this directly into account if it cared not only about advertiser surplus but also about viewer surplus, because the merger of two TV broadcasters that are close competitors on the "viewers' market" would give them leeway to increase their advertising volumes. The most straightforward and indeed necessary ${ }^{94}$ way to appropriately protect the

\footnotetext{
${ }^{91}$ As a matter of principle, ISPs are allowed to offer "zero tariffs" to end consumers pursuant to which the use of certain specific applications and services which are covered by the "zero tariff" will not be deducted from the data volume to which the end consumer is entitled. However, as recently held by the ECJ, such "zero tariffs" are incompatible with Art. 3 of Regulation 2015/2120 if, once that data volume has been used up, end users may continue to use those specific applications and services without restriction, while other measures blocking or slowing down traffic are applied to the other applications and services available. Joined Cases C-807/18 \& C-39/19, Telenor Magyarország, EU:C:2020:708. Yet, it appears that ISPs are otherwise indeed allowed to charge either the end consumers or the content providers to include specific applications and services in the "zero tariff". Further clarification can be expected from the pending cases C-5/20, Vodafone, and C-34/20, Telekom Deutschland.

92 Case IV/M.553, RTL/Veronica/Endemol, para 17.

${ }^{93}$ Case IV/M.1574, Kirch/Mediaset, para 11 and Case IV/M.779, Bertelsmann/CLT, para 15.

${ }_{94}$ Given the open wording of the SIEC test and the substantive criteria laid down in Art. 2(1)(b) of the EC Merger Regulation, which state that the "interests of the intermediate and ultimate consumers" have to be taken into account without specifying whether this relates only to the consumers in a given "market" that can be
} 
economic interests of the consumers as viewers against potential negative cross-group network effects is to acknowledge the existence of a viewer market. Even if one finds instead that the viewers are neutral to advertising, a merger between two ad-financed TV channels is likely to affect the profitability of each viewer. This change in profitability per viewer affects the incentives of the merged entity to attract additional viewers. Therefore, a merger is likely to affect the content choice of the TV channels, which is likely to impact consumer welfare. Thus, ignoring the unpaid side in any case amounts to ignoring the economic interests of viewers.

Even if the Commission has now clarified its position accordingly (as will be explained subsequently), the question of the existence of "viewers' markets", which has been kept open for quite a while, holds an important lesson: earlier clarification by the Commission, even if it was not strictly necessary in the context of the aforementioned merger decisions, could have prevented uncertainties among market operators and contributed to steer practice in the right direction at Member State level. ${ }^{95}$

\section{c) On the acknowledgement of zero-price markets in the world of digital platforms}

With the advent of the digitized world, the European Commission did acknowledge without hesitation that a "market" may also exist where a product is offered without monetary remuneration by the users. Thus, the EU Commission assumed, for example, in its abuse cases against Microsoft a market for streaming media players ${ }^{96}$ and for web browsers, ${ }^{97}$ even though these products were typically provided free of charge to final consumers. The (then) Court of First Instance confirmed this position. ${ }^{98}$ In the same vein, the Commission subsequently took for granted in its merger decisions Microsoft/LinkedIn, ${ }^{99}$ Microsoft/Skype ${ }^{100}$ and Facebook/WhatsApp ${ }^{101}$ that remuneration is not an indispensable characteristic for the existence of a market. Moreover, in the Google Shopping case, the Commission concluded that the relevant product markets were the market for general search services and the market for comparison shopping services, ${ }^{102}$ notwithstanding that the use of these services is offered free of charge to final consumers. Regardless of whether one finds the Commission's theory of harm in the Google Shopping decision convincing, the case nicely illustrates how certain conduct on a zero-price market might harm consumers in "paid markets": if a search engine "manipulates" its algorithm to give priority to its own affiliates, this may impede access to (paid-for) consumer markets and reduce the competitive pressure on those markets.

assessed for the purposes of merger control, it appears at least conceivable that the Commission factors these concerns into its overall assessment of whether the merger will lead to a SIEC. Nevertheless, it seems logical to argue that if the "viewers' market" is not a "market" for the purposes of merger control, then the viewers cannot be regarded as "consumers" within the meaning of Art. 2(1)(b) of the EC Merger Regulation. Therefore, to avoid such conclusion, it must be accepted from the outset that the "viewers' market" is a "market" even if the viewers are not charged a fee.

95 Note that, e.g., the German Bundeskartellamt still denied the existence of a viewers' market for free (adfinanced) in 2006. B6-103/05, Springer/Pro7Sat.1, p. 23.

${ }^{96}$ Case COMP/C-3/37.792, Microsoft, paras 402-425.

${ }^{97}$ Case COMP/C-3/39.530, Microsoft, paras 17-22.

98 Case T-201/44, Microsoft v. Commission, EU:T:2007:289, paras 927-933.

${ }^{99}$ Case COMP/M.8124, Microsoft/LinkedIn, para 87.

100 Case COMP/M.6281, Microsoft/Skype, paras 75 and 101-109.

101 Case COMP/M.7217, Facebook/WhatsApp, paras 31 and 34.

102 Case COMP/AT.39740, Google Search (Shopping), paras 154-250. 
While the issue of zero-price markets on one side of a (digital) two-sided platform ${ }^{103}$ has so far not been discussed by the ECJ in a competition case, ${ }^{104}$ there should be no doubt that the Court will approve the Commission's practice. Indeed, the Court has acknowledged the economic rationalities of two-sided platforms that underly zero-price markets, ${ }^{105}$ particularly as it considered the concept of a "service" within the meaning of Article 57(1) TFEU, which explicitly requires that it is "normally provided for remuneration". Thus, the Court argued, for example, that amateur athletes who participate in sports events without being paid by the organizers receive consideration as their sponsors are provided with publicity. ${ }^{106}$

\section{d) Conclusions}

To fully appreciate business activities in the context of two-sided platforms and to do justice to competition law's purpose of protecting consumer welfare, the legal concept of a "market" should not be interpreted as requiring a (visible) price to be paid by one party to the other. It is not sufficient to consider the activities on the "unpaid side" of the two-sided platform only by way of including them in the competition law analysis of the "paid side" of the platform. ${ }^{107}$ Such an approach would exclude certain activities and the ensuing positive or negative effects on consumer welfare altogether from the radar of competition law. Instead, competition practice should recognize straightforwardly that there can be "markets" for products offered free of charge, i.e. without monetary consideration from those who receive the product. While it is well understood that the supply of personal data and/or the attention to the platform can be regarded as consideration because it can be monetized by the platform, it is neither necessary $^{108}$ nor even beneficial to transform this insight into a legal concept of "remuneration". ${ }^{109}$

103 Note that the General Court held in the Microsoft case that "it does not follow from either Article [102d TFEU] or the case law on bundling that consumers must necessarily pay a certain price for the tied product". Case T-201/04 Microsoft v. Commission EU:T:2007:289, para 969.

104 The ECJ's broad interpretation of the scope of EU competition law adopted in Höfner, according to which even a public employment agency might be considered an "undertaking" as it pursues an activity that is "economic in nature", is not conclusive for the recognition of zero-price markets. It is based on the consideration that "[e]mployment procurement has not always been, and is not necessarily, carried out by public entities." Case C-41/90, Höfner and Elser v. Macrotron, EU:C:1991:161, para 22; see also Case C-82/01 P, Aéroports de Paris v. Commission, EU:C:2002:617, para 82 (on Art. 107 TFEU). Thus, the wide concept of an economic activity adopted in Höfner is based on the premise that the activity in question could also be (and in fact was) provided by private recruitment consultancy companies that, however, charge their clients. Since this is the core idea of the Court's reasoning, the ECJ's statement that "the application of Article [106] of the Treaty cannot obstruct the performance of the particular task assigned to that [public employment] agency in so far as the latter is manifestly not in a position to satisfy demand in that area of the markef' (ibid., at para 25 (emphasis added)) is not based on the recognition of zero-price markets.

105 This rationality is also embodied in the concept of "information society services", which is essential to Directive 2000/31/EC of the European Parliament and of the Council of 8 June 2000 on certain legal aspects of information society services, in particular electronic commerce, in the Internal Market ("Directive on electronic commerce"). O.J. 2000 L 178/1. While the concept only covers those services normally provided for remuneration, recital 18 of the Directive clarifies that "information society services are not solely restricted to services giving rise to on-line contracting but also, in so far as they represent an economic activity, extend to services which are not remunerated by those who receive them, such as those offering on-line information or commercial communications, or those providing tools allowing for search, access and retrieval of data". See Case C-484/14, Mc Fadden, EU:C:2016:689, paras 36-43.

${ }^{106}$ Case C-51/96, Deliège, EU:C:2000:199, paras 56-57.

107 But cf. Sousa Ferro, op. cit. supra note 1, at 264-266.

108 This may be different if "remuneration" is explicitly required as, for example, in the case of Art. 57(1) TFEU.

${ }^{109}$ But cf. Newman "Antitrust in zero-price markets: Foundations", 164 U. Pa. L. Rev. (2015), 149-206, at 163. 
Consequently, a "market" as a concept of competition law should be understood as consisting of transactions between two or more parties, of which at least one acts for economic purposes. ${ }^{110}$ The latter is apparent in cases where a product is provided for remuneration. Moreover, in cases where a product is offered free of charge, it suffices to demonstrate that the activity is part of a broad or a long-term strategy of the platform operator to generate revenue. This definition of a "market" is meant to exclude essentially (only) activities that involve the exercise of power by public authorities and philanthropic activities. In the digital sphere, the latter category would include in particular Wikipedia, non-commercial blogs, and noncommercial donation-based crowdfunding platforms. The relevant provisions of EU competition law can straightforwardly be construed accordingly. ${ }^{111}$ While this is in line with the Commission's current practice, it would be a helpful signal to firms, but also national authorities and courts, for the Commission to explain and refine its approach accordingly.

\section{Market delineation and homing decisions}

If two-sided platforms offer intermediation services, it is important to take into account the users' homing decision: if they make discrete choices between the offerings provided by platforms (and possibly non-platform providers of substitute services) they single-home, whereas they multi-home if they may decide to consume multiple offerings. ${ }^{112}$ In a media context, viewers are single-homers if in the relevant period they pick one of the offerings. For example, a person may watch television only for the news and decide which news show to watch. Such a person is a single-homer.

Investigating whether and at which costs users may multi-home is essential for market definition and the assessment of market entry barriers in the context of two-sided platforms. This is above all because even strong positive network effects do not lead to consumer lock-ins on their own, but only in conjunction with coordination problems. ${ }^{113}$ However, the problem of miscoordination can be mitigated in the case of multi-homing because in this case there is no first-mover risk involved if a consumer uses a newly entered platform. ${ }^{114}$

\footnotetext{
110 Note that a reference to the concept of an "economic activity" as it has been developed in particular by the ECJ as an element of the EU competition law concept of an "undertaking" would not be helpful to clarify the point because this concept for its part presupposes an idea of what constitutes a "market". See Case C180/98, Pavlov, EU:C:2000:428, para 75 ("It has . . been consistently held that any activity consisting in offering goods and services on a given market is an economic activity"; emphasis added). See also Advocate General Maduro, Case C-205/03 P, FENIN v. Commission, EU:C:2005:666, para 13.

111 Given the primary law character of Arts 101 and 102 TFEU, a legislative intervention would in any case only be conceivable as an amendment of the EC Merger Regulation. The example of Germany, where the legislature inserted a provision that states that "[t]he assumption of a market shall not be invalidated by the fact that good or service is provides free of charge" (section 18(2a) of the Competition Act), teaches us that a legislative intervention does not end all legal uncertainty: While it has been clarified that a "market" does not require an exchange that involves remuneration, the Bundeskartellamt considered that it has not yet been clarified whether or not a "market" requires a contractual relationship or any other kind of (mutual) exchange between the platform and its users to be present. In Facebook, the authority left this question open, arguing that in any case there was a contract between Facebook and its private users. In addition, the authority stated that the transfer of data could also be regarded as part of an exchange between Facebook and its private users. Case B6-22/16, Facebook, para 244.

112 In the economic literature, this distinction between single- and multi-homing has been elaborated in particular by Armstrong, "Competition in two-sided markets", 37 Rand Journal of Economics (2006), 668-691.

113 See infra note 163 and accompanying text.

114 Therefore, despite the outstanding positive direct network effects among the users of its social networking services, it is not clear whether Facebook must be considered a separate market. This was considered but ultimately left open by the Bundeskartellamt in Case B6-22/16, Facebook, paras 272-276. See also Waller, "Antitrust and social networking", 90 N.C. L. Rev. (2011-12), 1771-1805, at 1799 ("If Facebook's
} 
Taking a closer look at what counts as a single-homing and what as a multi-homing decision, consider platforms matching transport services to travellers. For example, if a traveller needs transport from an airport to the city centre, this is clearly a discrete-choice problem in terms of which product to consume. However, when we speak of single-homing versus multihoming in a platform context, we ask whether a consumer has to decide on the particular platform or provider before actually choosing a particular consumption plan. If a traveller decides which mode of transport and associated provider of this transport to choose before deciding on the particular consumption, then we talk of a single-homing traveller. For example, if a traveller who has installed the Uber app takes Uber as the starting point of her transport decision and checks for available rides on Uber, but for alternative transport possibilities only if dissatisfied with the available offers, we may want to classify her as a singlehoming user. ${ }^{115}$ Correspondingly, somebody who first checks for the availability of a ride by local train and considers alternative means of transport only if dissatisfied with the local train offer is classified as a single-homer. By contrast, a traveller who checks offers, for instance, on Uber and other transport platforms before deciding what to do can be considered a multihomer in the sense that she uses the information services by all information providers.

In our transport example, to the extent that individual providers of transportation services can list on alternative platforms, these transport providers can reach travellers through multiple channels (e.g. this holds if a van service can list on Uber as well as on other transport platforms). Hence, the degree of multi-homing by travellers affects the substitutability of platform listing services from the viewpoint of a provider of transport services and, as a consequence, also the latter's homing decision. It could be that a stable pattern of single-homing/multihoming on the two sides emerges. ${ }^{116}$

What is more, a platform may affect the homing decision on one side through contractual clauses as, for example, in the case of exclusivity clauses that tie a seller to an e-commerce platform. If contracts enforce single-homing on one side, an immediate implication is that services provided by platforms (and other undertakings offering substitutes) to this group of users belong to one market.

Finally, it must not be overlooked that homing decisions on one side may to a great extent depend on homing decisions on the other side. Let us consider for illustration an area in which two rival ride-hailing apps are available. If most drivers offer their services at any point in time on both apps, there are likely to be few gains for travellers from using both apps simultaneously; thus, travellers have weak incentives to be multi-homers. By contrast, if most drivers single-home (in a given time interval), it is more beneficial for travellers to multi-home

market dominance remains durable, the question of market power becomes easier over time as network effects and data lock-in make it increasingly likely that Facebook is a market unto itself").

115 Bundeskartellamt, cited supra note 65, refers to this kind of user behaviour as "sequential multi-homing". Similarly, a user who constantly uses one platform as default option but has, nevertheless, subscribed with a second platform in order to hedge against the risk of a system failure or the like (see, e.g., Case M.4523, Travelport/Worldspan, note 15) should be considered a single-homer.

116 Further consequences of such a framework for market definition are discussed infra in the following section, III.3.b). 
- that is, to check for availability and rates of transport offers on both apps. To acknowledge this interdependence is crucial as homing patterns on the two sides may change over time and, therefore, market delineations may have to respond.

\section{b) The multi-homing/single-homing framework}

Where users on one side of competing two-sided platforms single-home, these platform services are substitutes belonging to the same market. If, however, users on the other side multi-home, each platform provides monopoly access to its set of users on the single-homing side. Thus, for given user behaviour on the single-homing side, each platform acts as a monopolist vis-à-vis users on the multi-homing side. This suggests that there is a market for each platform regarding the service provided to the multi-homing side. ${ }^{117}$

Based on this consideration, the European Commission assumed the existence of a market for app stores for the Android mobile operating system, which is dominated by Google's app store. This rests upon the assumption that consumers are single-homers as they make a discrete choice to use a device based on Android's, Apple's or another firm's operating system, while app developers tend to be multi-homers. ${ }^{118}$

It is important to see, however, that the monopoly power on each such market may be mitigated through interaction with the other user group. ${ }^{119}$ More specifically, it may be the case that large parts of the revenues that are generated on the monopolized side are passed to the users on the other side. ${ }^{120}$

Moreover, in the Commission's practice, the described multi-homing/single-homing framework has not always been considered in the context of market definition. In Travelport/Worldspan, the EU Commission recognized that platforms that offer electronic travel distribution services through a GDS (global distribution system) to travel agents (TAs) and travel service providers (TSPs) typically face multi-homing on the side of the TSPs and single-homing on the side of the TAs. ${ }^{121}$ The Commission stated this feature only as part of its

117 A comparable approach underlies the regulation of fixed and mobile termination rates: Where consumers are subscribed to a network operator, only this operator may terminate calls made to these consumers. Hence, operators of a telecommunication networks are regarded as having a monopoly position in the market for the termination of calls on their own network. See Recital 3 of Commission Delegated Regulation (EU) ....... of 18.12.2020 supplementing Directive (EU) 2018/1972 of the European Parliament and of the Council by setting a single maximum Union-wide mobile voice termination rate and a single maximum Unions-wide fixed voice termination rate.

118 Case AT.40099, Google Android, para 306. An appeal is pending before the General Court (Case T-604/18 Google and Alphabet v. Commission).

119 See infra section IV.1.

120 The conventional wisdom about pricing in such a situation has been taken up, for example, by the Bundeskartellamt, cited supra note 65, p. 58: "this led to a monopolistic price on the multi-homing side, while the price on the single-homing side would be fairly low as a result of platforms competing for users on this side. In this respect, this may result in an inefficient price structure despite potentially intensive platform competition (on the single-homing side)." This suggests that if the side that multi-homes were instead to single-home (e.g. because of contractual restrictions), while the single-homing side continues to do so for technological reasons, prices would rebalance and lead to lower prices on the side that initially was multi-homing. As Belleflamme and Peitz, "Platform competition: Who benefits from multi-homing?" 64 International Journal of Industrial Organization (2019), 1-26 shows in a formal analysis, prices on the two sides indeed move in opposite directions. However, it is a priori not clear in which direction. The reason is that monopoly prices may actually be rather low as platforms may have an incentive to attract many users on the multi-homing side.

121 Case M.4523, Travelport/Worldspan, para 15. 
general description of the market for electronic travel distribution services through a GDS. ${ }^{122}$ The Commission only referred to the multi-homing/single-homing framework ${ }^{123}$ when discussing potential theories of harm through non-coordinated effects and, therefore, assessing inter alia whether "the merger would allow the merging undertakings to use their strong market position downstream vis à vis TAs in order to increase prices vis à vis TSPs upstream ('vertical cross market effects')"124

This illustrates that it is (at least to some degree) functionally interchangeable whether the nature of the users' homing decision is taken into account at the stage of market definition or (only) when considering the actual or potential effects on competition of a merger or any other relevant market conduct of the platform. In both ways, a competition analysis can consider that this framework enables a two-sided platform to exercise significant market power vis-àvis the multi-homing side. While the former way, i.e. the recognition of a market for each platform, is a straightforward and consistent reaction to this framework, the latter approach is more flexible. Hence, it may be regarded as preferable in cases without a clear-cut multihoming/single-homing setting but where the homing decisions of the different user groups are essentially in line with this scenario and therefore confer at least a significant degree of market power vis-à-vis the side on which multi-homing is prevalent. However, competition practice should not rashly discard the option of acknowledging a market for each platform to do justice to a multi-homing/single-homing framework, because otherwise there is a risk that this characteristic will not be given appropriate weight in the course of balancing the various factors.

\section{Multiple markets on one side of a platform}

Following a multi-markets approach, two-sided platforms offer intermediation services on markets on each side. However, in many real-world cases, the intermediary offers intermediation services for many different products and caters to heterogeneous user groups on each side. This observation is not restricted to two-sided platforms: for instance, electronic retailers typically offer a wide variety of products to heterogeneous consumers.

\section{a) Multi-purpose platforms}

Most e-commerce platforms make offerings in multiple product categories and consequently consumers may assess a number of products in different product categories and offered by a variety of vendors. An intermediary that offers intermediation services to consumers then operates in multiple markets, offering intermediation services for different product categories.

For example, Ebay carries a large variety of different product categories. Each of those may be considered a separate market if users visit Ebay in search for a product of a certain category. For example, if somebody wants to buy furniture online, she may decide to search via Ebay, Amazon, Google Shopping or some online store such as the one provided by lkea. Her market conditions may be very different compared to those of somebody looking for collector coins on Ebay, as alternative channels through which such items can be purchased

\footnotetext{
122 lbid., paras 13-21.

123 Ibid., para 81.

124 lbid., para 72.
} 
are different. If this is so and consumers tend not to search for furniture and collector coins at the same time, there are independent markets for the intermediation service for collector coins and furniture. Much in the same vein, for example, the Bundeskartellamt ascertained, in the context of the clearance of a merger that involved the two largest department store chains in Germany, that "there is no department store market as such", but instead defined retail markets for approximately twenty product categories. ${ }^{125}$ However, in the context of ecommerce, markets are often linked through demand-side economies of scope, e.g. because consumers store some search results from different product categories in their wish list or because they benefit from reduced delivery fees and improved delivery speed - some of these benefits may be part of a subscription service such as Amazon Prime that is particularly attractive for high-volume consumers. ${ }^{126}$

\section{b) Regional markets}

Digital platforms often scale up and serve a whole country and, in many cases, multiple countries. User behaviour on the two sides of the platform is decisive for whether there are multiple regional markets on each side or one inter-regional market. For instance, a dogsitting platform caters to dog owners and dog sitters. These are typically local markets (as the dog stays put) from the dog owner's perspective, as she is seeking somebody to do the dog-sitting in her home town and uses the platform to find a match. These are also local markets from the dog sitter's perspective as she is unlikely to change town to be able to do the dog-sitting somewhere else. Thus, there are multiple regional markets on each side.

The same may be correct for the services offered by online dating platforms catering to people looking for a long-term relationship. As we have explained above, it is preferable to assume two separate markets for the two user groups, i.e. for men and women who are looking for a partner. ${ }^{127}$ If the typical user is not willing to move or to start long-distance commuting for a relationship and, therefore, users commonly restrict their search to the locality or the region where they live, ${ }^{128}$ one can distinguish multiple regional markets. ${ }^{129}$ This market definition also takes account of the observation that platforms may enter the market by initially offering their services only to users in one agglomeration, with the prospect of then extending their services to other cities and regions. ${ }^{130}$

However, where multiple local or regional markets can be identified on only one side of a platform, it is essential not to ignore that these markets are linked through indirect feedback effects. These may occur as the demand of the users on the other side of the platform is supra-regional. Let us imagine a platform for the Mediterranean that allows local car rental businesses to offer their services to tourists. If the car rentals only operate locally at the various tourist destinations, the conditions of competition may differ significantly between these

\footnotetext{
125 Bundeskartellamt, 9 Nov. 2018, B2-106/18, Karstadt/Kaufhof, case summary, pp. 2-3.

126 This is reminiscent of one-stop shopping; see infra Section III.4.c).

127 See supra section III.1.b).

128 Bundeskartellamt, 22 Oct. 2015, B6-57/15, Parship/Elitepartner, para 125.

129 Despite this observation and even though it identified regional platforms, the Bundeskartellamt opted for a national market delineation. Bundeskartellamt, 22 Oct. 2015, B6-57/15, Parship/Elitepartner, para 126. This entails, however, the risk to underestimate market power at the regional level.

130 Bundeskartellamt, 22 Oct. 2015, B6-57/15, Parship/Elitepartner, para 128.
} 
destinations and it would be reasonable to delineate multiple local markets on this side of the platform. Yet, if we further assume that the typical customers on the other side of the platform are tourists who repeatedly use the platform to rent a car at their respective holiday destination, it becomes apparent that the market power the platform may enjoy vis-à-vis car rentals that operate, for instance, in Spain is highly dependent on how attractive the platform is to local car rental businesses that operate in Greece or Cyprus.

c) One-stop vs. multi-stop shopping

Markets may need to be considered in connection with each other if consumers substitute between product categories or tend to buy product bundles. ${ }^{131}$ This can be easily illustrated with a view to shopping in physical stores. If one-stop shopping is predominant, ${ }^{132}$ markets for different product categories that consumers consider buying are interdependent. ${ }^{133}$ In ecommerce, since there are no physical transport costs and checking out is simpler online than offline, there are reasons to expect less one-stop shopping than in offline retailing. However, lower delivery costs per unit may be a reason for consumers to go for one-stop shopping. Whenever there are successful specialized shops, this suggests that (unless there are other advantages of being specialized) at least an important fraction of consumers are not one-stop shoppers or consider only specific product categories because otherwise specialized shops would be at a disadvantage. Understanding purchase behaviour is essential to identify which intermediation services provided to consumers are interdependent and which ones are independent.

We may conclude, therefore, that multiple markets on one side may be linked with each other if users have positive opportunity cost of visiting a platform. Consequently, these markets should not be analysed in isolation, but their interdependence must be accounted for.

\section{The SSNIP test}

European competition authorities (among others) use the hypothetical monopolist test to identify the substitutes to a given product or service that are part of the relevant market. The General Court regarded the SSNIP test as "a recognized method for defining the market at issue". Yet the Court emphasized that the EU Commission may also rely on "other tools ... such as market studies or an assessment of consumers' and other competitors' points of

131 See Schweitzer, Haucap, Kerber \& Welker, "Modernisierung der Missbrauchsaufsicht für marktmächtige Unternehmen" (2018), p. 72 ("Depending on market conditions in the distribution, in particular the habits of those demanding goods or services via the platform, intermediation power would be rather product- or product group-specific or, if assortment effects are significant, with a view to a whole range of goods." (our translation)).

132 Note that the Bundeskartellamt, clearing a merger of two department store chains, ascertained that "[i]n department stores consumers are able to buy products of various product categories during their visit but generally do so only to a very limited extent as examinations have shown (emphasis added)." Bundeskartellamt, 9 Nov. 2018, B2-106/18, Karstadt/Kaufhof, case summary, p. 2.

133 One-stop shopping is, for instance, an important precondition for a retailer to carry loss leaders. An important observation is that one-stop shopping may make products that are substitutes when consumers are already at the shop complements at the earlier stage when they decide whether to show up in a particular marketplace. Consider two products, A and B. A price decrease of product A reduces the relative attractiveness and thus the demand of product B. However, under one-stop shopping, consumers find visiting the marketplace more attractive. The demand for product $B$ from additional consumers visiting the marketplace may overcompensate the demand lost to product $A$ from consumers who were to visit under the initial prices. If this is the case, products that are substitutes under multi-stop shopping become complements under one-stop shopping. 
view". ${ }^{134}$ The Commission has to make an overall assessment of indicative factors without assuming a hierarchy between different types of available evidence. In particular, there is no requirement to prioritize technical evidence over non-technical evidence. ${ }^{135}$

According to the SSNIP test, the relevant market is defined as the smallest product group such that a hypothetical monopolist in control of this product group could profitably sustain a small but significant non-transitory increase in price. ${ }^{136}$ To answer the question of whether a hypothetical monopolist could impose a price increase, one needs to ask whether such a price increase would be profitable. Hence, the issue is whether selling a smaller quantity at a higher price would be more profitable than selling the initial quantity at the initial price. Whether this is the case depends on how sensitively demand reacts to a price change, i.e. it depends on the elasticity of demand. ${ }^{137}$

In its Booking.com decision, the French Autorite de la concurrence relied on the SSNIP test ${ }^{138}$ to define the product market on the side of the platform where intermediation services are supplied to the hotels. The competition authority started with the hypothesis that the relevant product market comprises the reservation of overnight stays in French hotels via online reservation platforms and online travel agencies. ${ }^{139}$ The authority then, first, argued that the hotel-keepers did not consider other distribution channels such as the hotels' websites, metasearch engines (including hotel comparison sites ${ }^{140}$ ) and search engines to be substitutes for the use of an internet reservation platform. ${ }^{141}$ Second, the authority referred to a statement by Booking.com, which had argued that most hotels would not have sufficient means to ensure their visibility on the internet through meta-search engines and search engines. ${ }^{142}$ Based on these considerations by the hotels and Booking.com, the competition authority concluded that a small but significant increase of the commissions charged by a hypothetical monopolist platform would not result in such a significant shift of demand to other distribution channels as to make the price increase unprofitable. ${ }^{143}$ Thus, the authority saw its hypothesis on the definition of the product market confirmed.

The Autorité de la concurrence applied the SSNIP test to the market on one side of the platform without (explicitly) considering interrelations with the other side of the platform, i.e. the market for intermediation services offered to consumers looking for a hotel. Since consumers on Booking.com are not directly charged by the platform, their decision is only affected by the

\footnotetext{
${ }^{134}$ Case T-699/14, Topps Europe Ltd v. Commission, EU:T:2017:2, para 82.

135 See Case T-342/07, Ryanair v. Commission, EU:T:2010:280, para. 136; Case T-175/12, Deutsche Börse v. Commission, EU:T:2015:148, para 133.

${ }^{136}$ Market Definition Notice, cited supra note 6, paras 15-19 and 40. In its merger decisions, the Commission does regularly refer to the SSNIP test. See, e.g., Case M.1806, AstraZeneca/Novartis, paras 35 and 59; Case M.2187, CVC/Lenzing, paras 25-26; Case M.2420, Mitsui/CVRD/Caemi, para 11; Case M.3149, Procter \& Gamble/Wella, para. 38.

137 In its Market Definition Notice, cited supra note 6, paras 15-19, the European Commission refers to the SSNIP test only with regard to demand substitution. It is noteworthy that supply-side substitutability could be assessed correspondingly. See Di Mauro, "Refining the retail markets for audiovisual products", 48 European Competition Law Review (2003), 384-393, at 385.
}

138 Autorité de la concurrence, 21 Apr. 2015, Décision n 15-D-06, Booking.com, para 99.

139 Ibid., para 100.

140 Ibid., para 45.

141 lbid., para 100.

142 lbid.

143 lbid. 
hotel prices that prevail on the different distribution channels (taking service provision by the platform as given). The question then is whether an increase in commissions affects consumer choice through prices charged by hotels. Under wide price parity clauses, hotels may increase their prices in response to commissions by some amount, but they have to do so on all distribution channels on which they are active. Thus, in the present case it is unlikely that consumers' substitution patterns are affected significantly (there may be fewer total bookings but the relative shares of the distribution channels are unlikely to change much). While, therefore, for the application of the SSNIP test, the interdependencies between price effects on the two sides of the platform actually appear negligible, it would be desirable for a competition authority to state such an assumption explicitly. What is more, the case nicely illustrates that the relevance of the said interdependencies may be tied to the particular contracting environment: ${ }^{144}$ absent price parity clauses, the market may have to be defined wider as consumers may substitute away from higher prices on Booking.com after an increase of commissions. Thus, in general, when applying the SSNIP test, taking into account the interrelation with the other side may lead to a different definition of the market.

When applying the SSNIP test to two-sided platforms charging both user groups, different ways of increasing prices can be considered: the hypothetical monopoly intermediary could be thought of as raising (i) the sum of prices while optimally adjusting the price structure, (ii) all prices together while keeping the price structure fixed, (iii) each of the prices separately, allowing the other prices to be adjusted optimally, or (iv) each of the various prices while keeping the other prices fixed. ${ }^{145}$ Using (iv) as the default option, ${ }^{146}$ if there are mutual positive cross-group effects, then a drop in user participation as a result of a price increase on one side generates feedbacks that further reduce participation. To apply a one-sided SSNIP test without taking into account such feedback effects risks defining markets too narrowly. ${ }^{147}$

When the Higher Regional Court in Düsseldorf upheld a Bundeskartellamt decision ${ }^{148}$ to block a merger involving platforms for ticketing services, the Court formulated as a guiding principle that the SSNIP test was not "sufficiently conclusive in case of two-sided markets because it cannot adequately capture the feedback effects between different market sides". ${ }^{149}$ But this does not hit the nail on the head - the problem of capturing the crossgroup network effects is not a problem specific to the application of the SSNIP test but arises in general when assessing demand-side substitutability in two-sided markets. While it is cor-

\footnotetext{
${ }^{144}$ Note the further complication that, in this case, it is precisely this contractual setting whose competitive assessment is at issue. We submit that when defining markets in such a context, as market definition is one of several steps to analyze the competitive situation without legal intervention, it must be presumed that the agreement or other practice under review is effective because market definition is one of several steps to analyse the competitive situation without legal intervention.

145 Belleflamme and Peitz, Industrial Organization: Markets and Strategies, 2nd ed. (CUP, 2015), p. 676.

146 This stands in contrast to Crémer, de Montjoye and Schweitzer, op. cit. supra note 17, p. 45. In line with our view, Katz and Sallet, op. cit. supra note 86, at 2159, suggest "consider[ing] price changes on one side of the platform while holding prices on the other side constant and examining whether there are significant, plausible feedback effects. If there are no such effects, then focusing on a single side manifestly will give a clear overall picture. But if there are feedback effects, then they must be taken into account to avoid reaching misleading conclusions."

147 Filistrucchi, "Market definition in multi-sided markets" in OECD, Rethinking Antitrust Tools for Multi-Sided Platforms (2018), pp. 37-51, at 46.

148 Bundeskartellamt, 23 Nov. 2017, B6-35/17, CTS Eventim/Four Artists.

149 OLG Düsseldorf, 5 Dec. 2018, VI-Kart 3/18(V), Ticketvertrieb, juris, principle 2.
} 
rect that the implementation of the SSNIP test needs adaptation and is significantly more difficult in the context of two-sided platforms, this is only an expression of the general challenges for an assessment of demand-side substitutability in two-sided markets.

The SSNIP test can be seen as a thought experiment ${ }^{150}$ that helps to gain clarity in the application of demand-side substitutability; it may serve "as a framework . . . onto which qualitative evidence is applied (for example views on substitutability from consumer groups, industry analysts or firms that are informed by verified observations on previous experience)". ${ }^{151}$ Thus, the Bundeskartellamt concluded, with regard to the applicability of the SSNIP test to two-sided markets, "[w]hat would be conceivable are surveys on the switching behaviour of platform users under certain modified overall conditions based on the SSNIP test's fundamental idea". ${ }^{152}$ In Facebook/WhatsApp, the Commission referred to a survey among advertisers, most of whom submitted that they were not likely to switch from search ads to nonsearch ads in the event of a 5 to 10 per cent price increase, and concluded that the market investigation supported a corresponding sub-segmentation of the online advertising market. ${ }^{153}$

A look at the practical application of the SSNIP test logic by the European Commission demonstrates how it may be useful even without considering empirical evidence. In Visa International, the Commission defined the inter-system market based on an analysis of demand for payment instruments from both merchants and cardholders. ${ }^{154}$ Hereafter, the Commission assumed, inter alia, that neither cash nor cheques should be considered substitutable for payment cards. To justify this assumption with regard to merchants, the Commission argued that:

such non-card payment instruments are not at all substitutable with cards, since the loss of revenue for merchants from ceasing to accept all cards would be far greater than the loss of revenue from increasing their general level of prices by the amount of any small but sustained increase in merchant fees for all cards. ${ }^{155}$

This application of the SSNIP test logic shows, albeit only implicitly, the interrelation with the general considerations on demand-side substitutability in two-sided platforms and, more particularly, serves as an example of how demand-side substitutability may be asymmetric between two user groups of a (matching) platform. ${ }^{156}$

\footnotetext{
150 See Market Definition Notice, cited supra note 6, para 15 (SSNIP test as a "speculative experiment").

151 Pike, "Introduction and key findings" in OECD, Rethinking Antitrust Tools for Multi-Sided Platforms (2018), pp. 9-34, at 15 .

152 Bundeskartellamt, cited supra note 65, p. 41.

153 Case COMP/M.7217, Facebook/Whatsapp, para 76. Ultimately, the Commission left open whether segments of the online advertising market constituted relevant product markets in their own right. Ibid., para 79.

${ }^{154}$ Case COMP/29.373, Visa International - Multilateral Interchange Fees, para 46.

155 Ibid., para 48.

${ }^{156}$ A consumer who wants to purchase a certain product may ask herself (i) which payment system she prefers (e.g. cash or payment card) and (ii) from which merchant she would like to purchase the product. If there is a whole range of merchants that offer a comparable quality of customer service and if among those there are only some who do not accept the preferred payment system (e.g. a certain payment card), there will be no problem for a consumer to avoid that merchant and still purchase the product (including with the desired service quality). In contrast, in the same scenario, a merchant that does not accept the use of the payment system preferred by a certain group of potential customers will inevitably lose the option to do business with them.
} 
Further considerations are needed in zero-price markets and in markets in which platforms employ different business models with respect to monetization. If there is a zero price on one side of the market, the SSNIP test would need to consider an increase of the price in absolute terms (a percentage increase clearly will not do) or would require additional modifications according to which not price but product characteristics such as quality are varied to understand substitution patterns. In particular, if users are expected to react very sensitively to price, this does not necessarily imply that a broader market has to be defined. The reason is that a platform may not even consider charging consumers but rather aims at getting their attention by making attractive offers. Such a strategy may be highly profitable if a platform is able to convert attention into revenues made from a different user group.

Purely ad-financed platforms are a case in point. For example, applied to an ad-financed social network with an alleged dominant position, to understand substitution patterns the question is: by decreasing the quality of service offered by this social network, how much traffic would it lose (e.g. to other social networks or different offerings such as video streaming or online games)? Such an alternative test has been called SSNDQ (small but significant decreases in quality). In Google Android it was applied by the European Commission to consider the indirect constraint exercised by non-licensable smart mobile operating systems on Android and, therefore, to determine whether a separate market for licensable operating systems can be defined. ${ }^{157}$ However, a quantification is challenging, as it is often unclear how to operationalize a certain quality reduction. ${ }^{158}$

It also seems conceivable to substitute the relevant costs to be borne by the users (personal data and/or attention) for prices, an approach that has been referred to as SSNIC (small but significant non-transitory increase in (exchange) costs). Thus, with a view to ad-financed search platforms, it was suggested to consider "whether a market-wide five percent increase in the amount (or length, duration, etc.) of advertisements would cause search customers to substitute away to a different product". ${ }^{159}$ However, possible feedback on price and demand on the advertising market must not be ignored. A SSNIC test is therefore only meaningful without further complications if demand on the advertising market is almost perfectly elastic, i.e. if many customers on the advertising market are willing to buy advertising space at the same price.

Such implementation problems are arguably the reason why the Commission in the Google Shopping case did not consider the option to adapt the SSNIP test (at least not explicitly) but simply stated that "the SSNIP test would not have been appropriate in the present case because Google provides its search services for free to users". 160 The Commission could rely in this matter on the General Court's adjudication since the latter had held that the "SSNIP test may also prove unsuitable in certain cases, for example ... where there are free goods or

\footnotetext{
157 Case AT.40099, Google Android, para 267.

158 See for a suggestion of how the SSNDQ test could be applied to Facebook's offering of social networking services Gebicka and Heinemann, "Social media \& competition law", 37 World Competition (2014), 149172, at 158-159. See also the proposal by Hartman, Teece, Mitchell and Jorde, "Assessing in regimes of rapid technological change", 2 Industrial and Corporate Change (1993), 317-350, at 339-341.

159 Newman, "Antitrust in zero-price markets: Applications", 94 Washington University Law Review (2016), 49111 , at 66.

160 Case COMP/AT.39740, Google Search (Shopping), para 245.
} 
goods the cost of which is not borne by those determining the demand". ${ }^{161}$ However, the SSNIP test applied to quality changes can be used as a thought experiment.

If undertakings with different business models offer substitute services, the application of the logic of the SSNIP test becomes particularly challenging. As an example, we consider dating apps for heterosexual users. These apps possibly offer substitute services (the degree of substitutability depends on user behaviour). Some platforms charge subscription prices for male and female users, while others offer matching services at zero prices and run an adfinanced business model with advertisers as the third side. Depending on the identity of the platform, a price increase or an increase of advertising volume for one group of users (male or female users) could be considered.

We conclude that the SSNIP test serves conceptual clarity in the application of demand-side substitutability. Therefore, although it is often difficult to empirically implement the test in the context of two-sided platforms, it is a useful instrument for competition practice even if only applied as a thought experiment.

\section{Considering conceptual interdependencies: market definition, market power and cross-group network effects}

In order to assess the competitive position of two-sided (digital) platforms, the cross-group network effects between their different user groups must in particular be appreciated. Against this background, two aspects are especially significant to correctly understand and implement the role that market definition should play as an instrument to facilitate competition practice and, thus, were already assumed in the above analysis. First, market shares are less informative as a proxy for market power. Second, market definition must not conclusively determine the scope of a competition analysis.

\section{Market shares as a proxy for market power: mitigating and aggravating factors}

With a view on two-sided platforms, market shares have a relatively low significance for the assessment of market power. Given a firm with a certain market share, network effects may aggravate or mitigate the market power that follows therefrom.

Network effects can mean that the "coordinated" decisions of the economic agents have the consequence that it is not the platform with the highest-quality offer that dominates the market, but a different platform. If the latter is the incumbent platform and a higher-quality platform enters the market, the former may still prevail. As Shapiro and Varian nicely put it from the viewpoint of the incumbent platform, "[p]recisely because various users find it so difficult to coordinate to switch to an incompatible technology, control over a large installed base of users can be the greatest asset you can have". ${ }^{162}$

The entrant platform must overcome the problem that users have no incentive to switch if they expect most of the remaining users to remain on the established platform. If all users remain in the status quo unless unilateral switching to the new platform is more attractive,

\footnotetext{
161 Case T-699/14, Topps Europe Ltd v. Commission, EU:T:2017:2, para 82.

162 Shapiro and Varian, Information Rules: A Strategic Guide to the Network Economy (Harvard Business School Press, 1999), p. 185.
} 
barriers to entry will arise owing to user miscoordination. ${ }^{163}$ For one thing, a necessity for coordination may arise because users would otherwise forgo the strong positive direct network effects from which they want to benefit, for example when using social networking services. For another thing, the need for coordination may refer to the users on different sides of a two-sided platform who are linked through mutual positive cross-group network effects, as, for example, in the case of matching platforms. In order to convince users to switch in such a situation, the new platform may need to subsidize early users (in the case of a two-sided platform, on at least one side). The extent of such subsidization represents the level of entry barriers.

If, on the other hand, a new platform (for example, based on its reputation acquired in other markets) influences users' expectations in such a way that all potential users assume that the status quo will be replaced, there are no barriers to entry. ${ }^{164}$ The challenge is, thus, to identify the cases where network effects work in favour of an incumbent firm (and, thus, constitute an entry barrier) and those cases where they work in favour of entrant firms.

Moreover, digital platforms frequently operate on emerging and dynamic markets characterized by rapid growth (in which many unattached users arrive) and short innovation cycles. As was acknowledged by the General Court in Cisco, in such contexts "high market shares are not necessarily indicative of market power". ${ }^{165}$ However, as this cautious statement rightly points out, one must beware of generalizations and cannot avoid a case-by-case analysis of whether the characteristics of a market such as new product developments, the presence of new consumers and the "timing" of new product introduction ${ }^{166}$ actually point to relatively low entry barriers.

Aggravating and mitigating factors can easily be taken into consideration where the law does not foresee specified thresholds of market shares that are meant to function as indicators for a certain degree of market power. Most prominently, Article 102 TFEU applies to "undertakings of a dominant position within the internal market", and pursuant to Article 2(2) and (3) of the EU Merger Regulation the compatibility of a merger with the common market depends in particular on the question of whether the merger will result in the "creation or strengthening of a dominant position". While market shares have for a long time been used by authorities and courts to implement the concept of "dominance", 167 and the ECJ even established a presumption of dominance applicable to undertakings with a market share of 50 per cent or

163 Biglaiser, Calvano and Crémer, "Incumbency advantage and its value", 28 Journal of Economics and Management Strategy (2019), 41-48, review the economic mechanisms that lead to network effects-induced barriers to entry.

164 See, e.g., Wismer, Bongard and Rasek, "Multi-sided market economics in competition law enforcement", 8 JECLAP (2017), 257-262, at 261 ("Nevertheless, in some cases, network effects can also stimulate competition when possibly disruptive entrants or smaller merging firms benefit from network effects to catch up with large established firms").

165 Case T-79/12 Cisco Systems Inc. and Messagenet Spa v. Commission, EU:T:2013:635, para 69.

166 Barriers to entry are lower in markets in which new generations of products have to arrive at given dates. See Collyer, Mullan and Timan, "Measuring market power in multi-sided markets" in OECD, Rethinking Antitrust Tools for Multi-Sided Platforms (2018), 71-80, at 73.

167 Case C-85/76, Hoffmann-La Roche v. Commission, EU:C:1979:36, para 41. 
more, ${ }^{168}$ it has always been clear that market shares are only one of a multitude of factors that have to be considered to substantiate that a firm dominates a market. ${ }^{169}$

Where the law does, however, provide for specified thresholds of market shares that are used as an indicator of market power, the importance of cross-group network effects makes it clear once again that such provisions should not contain "hard" thresholds. The law should always provide for ways - be it through the structuring of substantive law or by way of procedural rules - to prevent "false positives" as well as "false negatives".

The EU block exemption regulations are a case in point. Their application typically requires that the market share of an undertaking does not exceed a certain threshold. ${ }^{170}$ But, for one thing, an undertaking that exceeds this threshold may still rely on an exemption pursuant to Article 101(3) TFEU, which, thus, functions as a catch-all provision for scenarios where the market share of a firm erroneously signals a certain degree of market power. For another thing, pursuant to Article 29 of Regulation 1/2003, the European Commission or the national competition authorities of the Member States may withdraw the benefit of an exemption regulation when they find that measures by undertakings that are covered by it have "certain effects which are incompatible" with Article 101(3) TFEU. This, therefore, forms a procedural mechanism to remedy the over-inclusiveness of a market-share threshold.

Instead of a focus on market share, competition practice concerned about persistent market power should focus their efforts on detailed case-by-case analyses of current and future barriers to entry. ${ }^{171}$

\section{Market definition must not (conclusively) determine the scope of the competi- tion analysis}

In the application of EU competition law, no clear and consistent position has been evolved as to whether or to what extent EU competition law requires or allows the balancing of proand anti-competitive effects or the netting of welfare effects on different groups of market participants. The main underlying reason for this is arguably the difficulties - quantification problems and distributional appraisals - that come along with such balancing exercises and inter-group comparisons of welfare. ${ }^{172}$ To give an illustrative example from competition practice: in a leading decision concerning a system of collective resale price maintenance for the trade of books, the European Commission pointed solely to the fact that the system denied the consumer the chance to decide whether or not she liked to pay a "service charge" and, thus, refused from the outset to engage in a discussion on the aggregate effects that such a coordination might have on consumer welfare. ${ }^{173}$

\footnotetext{
168 Case C-62/86, AKZO v. Commission, EU:C:1991:286, para 60.

169 See, e.g., European Commission, Guidance on the Commission's enforcement priorities in applying Article 82 of the EC Treaty to abusive exclusionary conduct by dominant undertakings, point 15. O.J. $2009 \mathrm{C} \mathrm{45/7.}$

170 See, e.g., Art. 3 of the Commission Regulation (EU) No 330/2010 of 20 April 2010 on the application of Article 101(3) TFEU to categories of vertical agreements and concerted practices. O.J. $2010 \mathrm{~L} \mathrm{102/1.}$

171 As was done, e.g., in Bundeskartellamt, 22 Oct. 2015, B6-57/15, Parship/Elitepartner, paras 184-193.

172 Lianos, "Some reflections on the question of goals of EU competition law" in Lianos and Geradin (Eds), Handbook on European Competition Law. Substantive Aspects (Edward Elgar, 2013) 1-84, at 57.

173 Case IV/428, VBBB/VBVB, para 54. The Commission also rejected the proposition that price maintenance would allow publishers to cross-subsidize books that were published in small print runs, arguing that the net efficiency effects the policy had on buyers were certainly negative. Ibid., para 56. Moreover, it is noteworthy that in GlaxoSmithKline Services the (then) Court of First Instance (CFI) stipulated that the
} 
In the context of a competition analysis of two-sided platforms, the important point to note is that, when it is acknowledged that a weighing of different and diverging effects is allowed or even required where these effects relate to a single market, then it must be allowed or required in just the same way where it concerns cross-group network effects on different user sides of a two-sided platform that, following a multi-markets approach, belong to different markets. While it may in many instances be reasonable to focus an impact analysis on a defined market, ${ }^{174}$ this does not mean that any effects outside the boundaries of a defined market must be ignored for the purposes of a competition analysis. Such an understanding would assign a legal meaning to market definition that is not appropriate to it. As mentioned above, the ECJ has stated this with desirable clarity in Cartes Bancaires, rejecting the General Court's view that the analysis of whether a restriction of competition within the meaning of Article 101(1) TFEU had occurred were to be restricted to the market defined on the "issuing side" of the payment card system, neglecting effects on the "acquiring side". ${ }^{175}$ Moreover, in its adjudications concerning both Article 101(3) TFEU ${ }^{176}$ and Article 2 of the EC Merger Regulation, ${ }^{177}$ the General Court took the view that market boundaries must not define the effects that may be taken into account for the necessary efficiency analysis. ${ }^{178}$ This confirms that the appropriate consideration of cross-group network effects between the different sides of a two-sided platform does not require the (inadequate) adoption of a single-market approach.

\section{Conclusion}

The thinking and practice of EU competition law is at various points structured by defining the relevant market. The gist of the approach is to identify the products and services offered by an undertaking and to understand substitute offers. While the concept of market definition may, as a matter of principle, be transferred to competition analyses of two-sided platforms, it needs to be amended and extended. Since two-sided platforms offer interrelated and often

Commission, when analysing efficiency effects of restrictions on parallel trade under Art. 101(3) TFEU, should have considered the pharmaceutical manufacturer's argument that the potential benefits a prevention of parallel trade may have for the final consumers would in any event outweigh disadvantages suffered by the wholesalers as the immediate consumers of the manufacturer. Case T-168/01, GlaxoSmithKline Services v. Commission, EU:T:2006:265, paras 273-274. The ECJ dismissed the Commission's appeal which was, among other things, also directed against this aspect of the judgment, but did so on the premise that the CFI had "simply set out the structure of GSK's arguments and the substance of those relating to the efficiency losses associated with parallel trade." Case C-501/06 P, GlaxoSmithKline Services v. Commission, EU:C:2009:610, para 116. In light of this, the CFI's statement should not be read as having implicitly endorsed a netting of welfare effects on different groups of market participants.

174 See, for example, Case C-234/89, Delimitis v. Henninger Bräu, EU:C:1991:91, paras 14-16.

175 See supra $\mathrm{n} 62$.

176 Case T-86/95, Compagnie générale maritime and Others v. Commission, EU:T:2002:50, para 343.

177 Case T-87/05, EDP - Energias de Portugal v. Commission, EU:T:2005:333, paras 147 and 236. But note that the Court at the same time emphasized that the "Commission must prohibit a transaction provided that the criteria of Article 2(3) of the Merger Regulation are satisfied, even in respect of only one of the relevant markets". Ibid., para 145.

178 Note the more restrictive position stated by the Commission, according to which it would only engage in a cross-markets efficiency-analysis under Art. 101(3) TFEU "where two markets are related" and "provided that the group of consumers affected by the restriction and benefiting from the efficiency gains are substantially the same." Guidelines on the application of Article 81(3) [now 101(3)] of the Treaty, O.J. 2004 C 101/97, para 43; see also ibid., at para 87 and Guidelines on the assessment of horizontal mergers under the Council Regulation on the control of concentrations between undertakings, O.J. 2004 C 31/5, para 79. 
complex products, and since the interdependencies between their different user groups have to be considered, market definition is more challenging and prone to error or even abuse.

Therefore, market definition in the context of competition practice on two-sided platforms must combine adequate economic reasoning with flexible legal thinking. It is crucial to understand in each case the nature of the offered products and services as well as the interrelations between the multiple connected sides and markets. These interrelations must, however, be considered not only for market definition but also for the analyses of the effects a certain practice may have on competition in the defined markets. Thus, competition practice in relation to two-sided platforms also requires understanding the specific limits to the significance of market definition. In this context, it is important to see that calculated market shares are less informative as an indicator of a two-sided platform's market power.

Because of the objective of market definition to structure and discipline competition analyses by authorities and courts, the true challenge is not only to adapt the conventional ideas and tools in a formally correct and consistent way but also to provide clear statements and practical guidance that makes market definition foreseeable and manageable also in the context of two-sided platforms. While one may argue about implementation details in individual cases, the Commission has so far found convincing answers to the conceptual challenges posed by the rise of digital platforms. However, it would help to see more explicit and clearer statements on the necessary conceptual adjustments. With the reform of the Market Definition Notice, the Commission has, first and foremost, the chance and the responsibility to provide market players with more legal certainty about its own thinking in this respect. In addition, the reform presents an opportunity to guide the Member States' courts and competition authorities, and possibly even to influence the future case law of the ECJ. 